\title{
Ammonite faunas from condensed Cenomanian-Turonian sections ('Tourtias') in southern Belgium and northern France ${ }^{*}$
}

\author{
W.J. Kennedy ${ }^{1}$, F. Amédro ${ }^{2}$, F. Robaszynski ${ }^{3}$ \& J.W.M. Jagt ${ }^{4}{ }^{*}$ \\ 1 0xford University Museum of Natural History, Parks Road, 0xford 0X1 3PW, United Kingdom. \\ 2 Rue de Nottingham 26, F-62100 Calais, France; and, Université de Bourgogne, UMR 5561, CNRS Biogéosciences, Bd Gabriel 6, F-21000 Dijon, France. \\ 3 UMONS, Faculté Polytechnique, rue de Houdain 9, B-7000 Mons, Belgium. \\ 4 Natuurhistorisch Museum Maastricht, de Bosquetplein 6-7, NL-6211 KJ Maastricht, the Netherlands. \\ * Corresponding author. Email: john.jagt@maastricht.nl.
}

Manuscript received: November 2010; accepted: July 2011

\begin{abstract}
In southern Belgium (Mons Basin and Tournai region) and northern France (area between Lille, Valenciennes and Maubeuge), condensed sequences have been referred to as 'tourtias' since the start of the nineteenth century. These levels correspond to a succession of trangressive systems tracts and generally appear as dark green, glauconitic and microconglomeratic facies. They are distributed all along the base of the more important transgressive systems tracts of the Cenomanian and basal Turonian from the Boulonnais (northwest France) to the Mons Basin (southern Belgium), through the Artois and Douaisis. Their age can now be determined more accurately by identification of their ammonite content, as housed in museums such as the Institut royal des Sciences naturelles de Belgique (IRScNB, Brussels) and the Musée d'Histoire naturelle de Lille (MHNL). Here material from the IRScNB collections is described, illustrated and discussed; specimens contained in the MHNL collections were described in a previous paper.
\end{abstract}

Keywords: Ammonoidea, Cenomanian, Turonian, tourtia, condensed sequences, Belgium, France, correlation

\section{Introduction}

It has long been known that condensed sequences, commonly known as 'tourtias', in the lower Upper Cretaceous of southern Belgium and northern France yield distinctive ammonite faunas that can be used to date these sections and provide correlations with sections elsewhere in Europe and further afield (Robaszynski et al., 2002). Originally, at the start of the nineteenth century, the term 'tourtia' was used by miners to refer to greenish, granular rocks encountered between the overburden and the coal-producing levels. The origin of the word is related to the resemblance of this rock type to the residues left after the production of colza oil, 'tourteau-tourtiau-tourtia' (Drapiez, 1823; d'Archiac, 1847). Later, during the construction of numerous collieries in the Walloon part of Belgium and in northern France, a 'tourtia' represented a conglomeratic or microconglomeratic rock, formed of pebbles or of pieces of rock of pre-Cenomanian or Cenomanian age in a chalky or marly matrix, occasionally sandy and ferruginous. Most often the rock is glauconitic and of a dark green colour.

Based on studies by Dumont (1849), F.L. Cornet \& Briart (1866), Barrois (1878), Gosselet (1881, 1904-1914), Cayeux (1889) and Marlière (1936, 1939a-c), it became apparent that there were various successive levels of tourtias, of different ages. Marlière (1957), Polvêche (1957) and Robaszynski (1980b) summarised data in various entries in the 'Lexiques'. The various tourtias encountered in quarries and penetrated in mine shafts have yielded numerous fossils, part of which are now housed in collections such as the ones at the Musée d'Histoire naturelle de Lille (MHNL) and the Institut royal des Sciences naturelles de Bruxelles (IRScNB).

* In: Jagt, J.W.M., Jagt-Yazykova, E.A. \& Schins, W.J.H. (eds): A tribute to the late Felder brothers - pioneers of Limburg geology and prehistoric archaeology. 
The ammonites in the IRScNB collections originate from tourtias in the Tournai area, the Mons Basin and from between Maubeuge and Valenciennes (Fig. 1). A revision of these faunas was initiated by two of us, WJK and JWMJ; independently, and unaware of this revision, FA and FR had been studying tourtia ammonites in the MNHL collections in recent years. Those specimens originate from the Boulonnais, Artois, the environs of Douai, Valenciennes, Maubeuge and Tournai, as well as from the Mons Basin. For illustrations of the most important species and a sequence-stratigraphic interpretation of the tourtias, reference is here made to Amédro \& Robaszynski (2010). The present paper assembles data from both studies; of note is that the IRScNB material comprises a number of novelties, such as Early Cenomanian ammonite taxa from Tournai, Onnaing, Hautrage and Bettrechies, not documented by Amédro \& Robaszynski (2010).

\section{Tourtia successions}

\section{Bettrechies quarry, northern France}

Detailed sampling at the disused SECAB quarry (Robaszynski, 1980a) has demonstrated a succession of various units (thickness: a dozen metres) overlying limestones of Givetian (late Middle Devonian) age which were exploited here (compare Fig. 7). From bottom to top (the fossil taxa listed are based on MHNL collections or personal observation) these are:

- Wealden facies - black clays with fragments of pyritised fossil wood, preserved on a palaeokarstic surface of the Givetian limestone (karst up to several metres in depth);

- 'Sarrasin' - 1 to 5 metres in thickness (as based on the section logged at the quarry); in those places where this facies is $5 \mathrm{~m}$ thick, several levels can be distinguished. At the base
Fig. 1. Locality map and presentday extent of Cenomanian (upper figure) and Turonian (lower figure) formations in southern Belgium and northern France (Mons Basin; area between Tournai and Maubeuge).
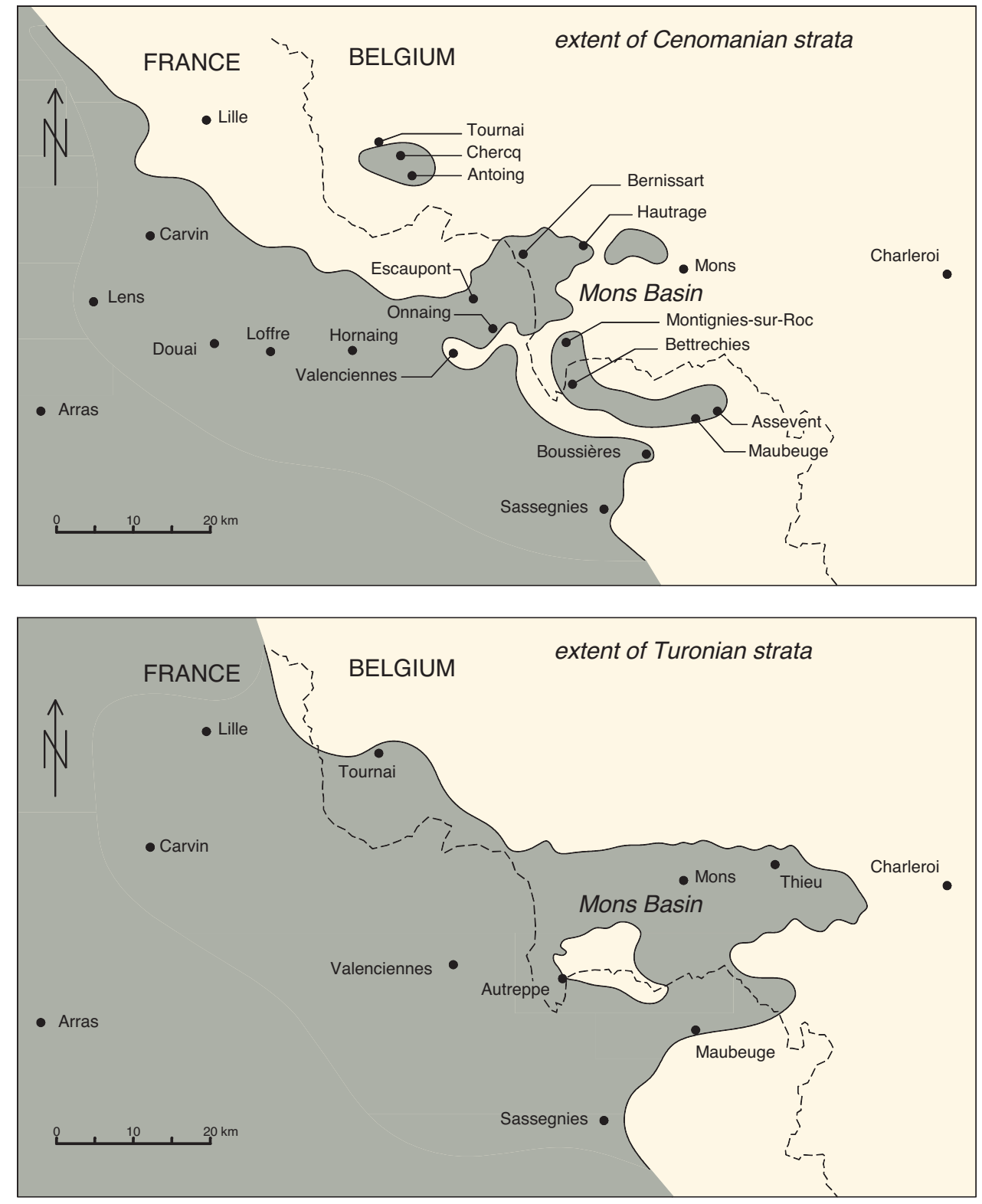
occur phosphatic gravels, with overlying these two metres of very coarse-grained, glauconitic calcirudites, with decimetresized boulders of Palaeozoic rocks and large-sized oysters forming a kind of conglomerate. An equivalent facies at Montignies-sur-Roc in southern Belgium (Fig. 1) has yielded Mantelliceras mantelli, probably from the Mantelliceras dixoni Zone (upper Lower Cenomanian). Overlying are two metres of glauconitic calcarenite which, together with the calcirudites, forms what is referred to as 'crumbly Sarrasin' (Fig. 7). This is capped by a complex hardground, c. 1 metre thick, constituting the really compact facies, the 'Sarrasin' proper. This hardground has yielded Cunningtoniceras inerme, Sciponoceras baculoides and Schloenbachia coupei, an association typical of the Acanthoceras rhotomagense Zone (lower Middle Cenomanian). The 'crumbly Sarrasin' and the Sarrasin proper constitute a lateral chronostratigraphic equivalent of the Tourtia de Tournai, as demonstrated below.

- Tourtia de Mons - 0n top of the Sarrasin hardground surface, which is perforated by lithophagid bivalves and covered in glauconite, follow three metres of variegated layers of a generally grey-bluish marly lithology. At the base, there is a horizon of black and phosphatic pebbles, which has produced fragments of Calycoceras cf. asiaticum, C. cf. picteti and Acanthoceras jukesbrownei (Fig. 7). Resting on the black gravels are 1.5 metres of glauconitic, bluish marls containing a level of cobbles and capped by a ill-defined hardground with A. jukesbrownei. The fossil content of the first subunit belongs to the A. jukesbrownei Zone (upper Middle Cenomanian). Overlying this is one metre of bluish marl with a thin hardground. Despite the fact that this level, which is capped by a perforated surface, does not contain any significant macrofauna, it may be assumed that the Calycoceras guerangeri Zone was originally present, of early Late Cenomanian age. In fact, this zone has been documented within the glauconitic chalk of the 'Tourtia de Mons' at Condé-sur-l'Escaut, at the entry to the Mons Basin, 5 kilometres northeast of Escaupont (Amédro \& Robaszynski, 2010, pl. 3, fig. 1). Filling the perforations is a darkish clayey marl (0.2-0.4 m in thickness), with Praeactinocamax plenus, Metoicoceras geslinianum and planktonic foraminifera such as Whiteinella archaeocretacea and Rotalipora cushmani, an association which defines the Metoicoceras geslinianum Zone (uppermost Cenomanian). It is these three metres of variegated layers which constitute the 'Tourtia de Mons', of latest Middle to Late Cenomanian age.

- Tourtia de Bettrechies - Another level with black, phosphatic pebbles appears above the 'plenus Marls'; it is this which has been referred to as the 'Tourtia de Bettrechies'. Overlying it are several metres of 'Dièves' or greyish marls which, when altered, turn beige in colour, and yield Inoceramus gr. labiatus. Sieve residues have furnished a microfauna with planktonic foraminifera of Early Turonian age, such as Helvetoglobotruncana helvetica, Marginotruncana pseudolinneiana and Dicarinella hagni. Higher up appears also the small brachiopod Terebratulina rigida, which documents the onset of the Middle Turonian.

\section{Abandoned quarries in the Tournai area}

South of Tournai (Figs 1,3), the Cretaceous cover in quarries where Carboniferous limestones were exploited, has been the subject of numerous studies since the beginning of the nineteenth century. Based on collections made by Charles Léveillé (donated by him in 1839 to the Société géologique de France), d'Archiac (1846) undertook to identify all specimens originating from the 'Tourtia de Tournay'. In his 'Rapport sur les fossiles du Tourtia' (d'Archiac, 1847), the list of species comprises numerous bivalves, gastropods, brachiopods (a plethora of terebratulids, i.e., 48 species, 37 of which were new), corals, echinoderms and more, yet but a single cephalopod, Ammonites varians Sow., which was not described nor illustrated. According to d'Archiac, this 'Tourtia de Tournay' had been laid down 'after the Gault period' (which would later become the Cenomanian) and he well noted (p. 346) the presence of 'Belemnites canaliculatus (var ? actinocamax) qui existait parmi les fossiles de Tournay (et) ne nous a point paru provenir de cette localité. This means that he had certainly realised the possibility that another, younger tourtia existed, but at another locality. It was Cayeux (1889), who described and understood the superposition of several tourtias in his 'Crétacé de Chercq près Tournay'. Barrois (1878, p. 374) had recorded a similar succession at Bellignies, a locality which corresponds to Bettrechies here, as had F.L. Cornet \& Briart (1866, p. 85) in Hainaut.

Today, the ideal and complete lithological succession is as follows, from bottom to top:

- Wealden facies - 0n Palaeozoic (Visean, middle Mississippian) black limestones, inclined and peneplained, clays and sands of Wealden type are occasionally preserved in palaeokarst (e.g., at Bettrechies).

- Tourtia de Tournai - This is the 'first' tourtia, which rests unconformably on the Palaeozoic basement. It is a compact conglomerate with large-sized cobbles and boulders of Palaeozoic rock, in a brown calcareous and ferruginous cement. Its thickness may vary from several decimetres to 1 to 1.5 metres. This is a condensed level, rich in fossils, details of which have first been presented and illustrated by d'Archiac (1847), who noted in particular the ammonite Schloenbachia varians, the echinoid Codiopsis doma and several brachiopods, such as Terebratula nerviensis, $T$. tornacensis and 'Terebratula' (= Orbirhynchia) mantelliana, illustrating its Early to Middle Cenomanian age.

- Tourtia de Mons - Above, the 'second' tourtia has a very different habit; this is a bed of between 2 and 20-30 centimetres in thickness, comprising marls, or 'Dièves', which contain centimetre-sized gravels of black phtanite and milky 
quartz, as well as brown phosphatic pebbles in a greenish marly to sandy, glauconitic matrix. At the disused Delwart quarry (Figs 3-5), this tourtia has yielded Praeactinocamax plenus, remanié elements of the underlying Tourtia de Tournai and even fossils reworked from the Carboniferous limestone basement. At the Bettrechies quarry, this level has been shown to contain planktonic foraminifera, in particular Rotalipora cushmani. Macro- and microfossil taxa are indicative of a Late Cenomanian age.

- Tourtia de Bettrechies - In some places, e.g., at Bettrechies, occasionally there is above the 'plenus Marls' a thin level of black pebbles, which testifies to a 'third' tourtia at the very base of several metres of yellowish 'Dièves' which produced Mammites nodosoides, Inoceramus labiatus, Orbirhynchia cuvieri and planktonic foraminifera such as Marginotruncana hagni and Helvetoglobotruncana helvetica, an association which dates this third tourtia as Early Turonian. However, it should be noted that very often the Tourtia de Mons and Tourtia de Bettrechies are not visibly differentiated, the whole being condensed and with an admixture of black pebbles and remanié Palaeozoic fossils, sometimes reworked cobbles from the Tourtia de Tournai, abraded fragments of $P$. plenus, 0 . cuvieri and $I$. labiatus, very rarely $M$. nodosoides, all in a chalky marl with glauconite grains. Having been dated as Early Turonian, this is the equivalent of the Tourtia de Bettrechies proper.

- Cenozoic silty clays - Above several metres of 'Dièves' follows a discontinuity surface occasionally marked by a basal gravel, above which follow clayey siltites of Thanetian (late Paleocene) age.

\section{Age of the ammonite assemblages}

All localities from which the specimens here revised originate are shown in Fig. 1, which also illustrates the current extent of Cenomanian and Turonian strata in the area. In Fig. 2, all lithological symbols used in Figs 4-7 are explained, while Fig. 3 shows the disused Delwart and du Cornet quarries, south of Tournai. Logs of the Delwart and du Cornet quarries are

\begin{tabular}{|c|c|c|c|}
\hline--- & marly chalk & ஃ০০ & pebbles and cobbles \\
\hline$\equiv=$ & marl & 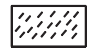 & glauconite \\
\hline 監到 & clay & $\cdots \cdots$ & phosphatic nodules \\
\hline 00 & nodular limestone & $y$ & Carboniferous limestone \\
\hline 肾 & glauconitic siltstone & G & ammonite \\
\hline 1 & sandstone & $\nabla$ & Praeactinocamax \\
\hline सास्या & hardground & $\smile \smile$ & Entolium \\
\hline कov & burrowed surface & & \\
\hline
\end{tabular}

Fig. 2. Key to symbols used in Figs 5-7.

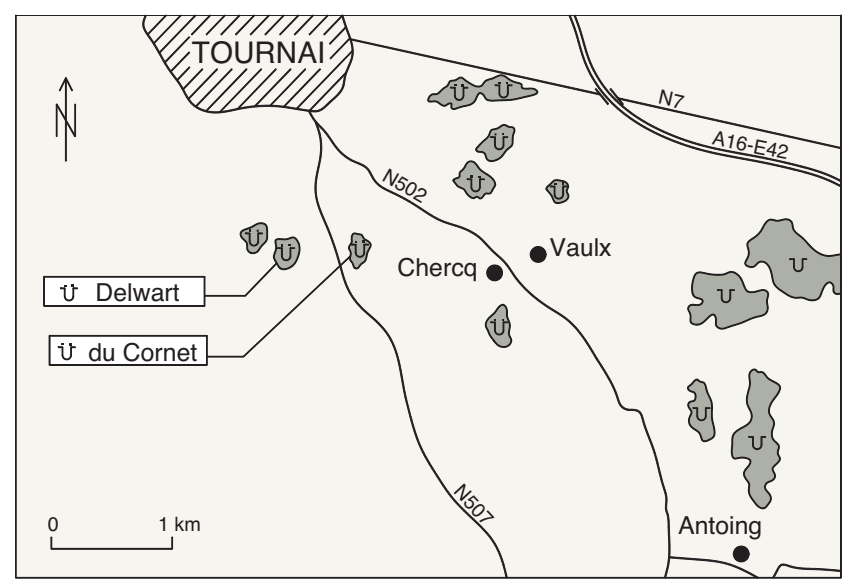

Fig. 3. Locality map of the two old quarries Delwart and du Cornet.

shown in Figs 4 and 5, illustrating the stratigraphic range and correlation of the Tourtia de Tournai, while Fig. 8 illustrates the development of sequences and systems tracts in northern France and southern Belgium, highlighting the position of the various tourtias.

Tourtia de Tournai (Tournai, Hainaut, southern Belgium) Internal moulds are brown, limonite coated, or retain limonitised shell material, and are of a buff granular limestone with scattered grains of glauconite, quartz and limonite. Preserved in this way are Schloenbachia varians, Sch. coupei (and passage forms from varians), Hamites simplex, Mesoturrilites corrugatus, Turrilites acutus, Sciponoceras baculoides, Sci. roto and Scaphites obliquus. Schloenbachia varians, Sci. roto and M. corrugatus indicate the Lower Cenomanian Mantelliceras mantelli to Mantelliceras dixoni zones; Turrilites acutus and other species the upper, Turrilites acutus Subzone of the lower Middle Cenomanian Acanthoceras rhotomagense Zone.

0ccurring as creamy-buff internal moulds, some with replaced shell of the same colour, predominantly preserved as micritic limestone with glauconite, quartz and limonite grains are Schloenbachia varians, Sch. coupei, Acanthoceras rhotomagense and Sci. baculoides. Possibly, these indicate horizons from the lower Lower Cenomanian Mantelliceras mantelli Zone to the lower, Turrilites costatus Subzone of the lower Middle Cenomanian Acanthoceras rhotomagense Zone. However, it is more likely that the range was uppermost Lower Cenomanian (Mantelliceras dixoni Zone) to the Turrilites costatus Subzone.

Labelled as coming from the 'Tourtia de Tournai' are dark brown to black phosphatic internal moulds of Lewesiceras sp. juv., resembling L. cenomanense Wiedmann \& Schneider, 1979 of late Late Cenomanian Metoicoceras geslinianum Zone age, or possibly even younger (compare Kaplan et al., 1998). Here, we consider these specimens to have been mislabelled; they may have originated from the Tourtia de Mons, of latest Cenomanian age. Similarly, a single specimen of Mammites nodosoides, of a comparable preservation and labelled 'Tourtia de Tournai', more probably came from the Tourtia de Bettrechies or from the 'Dièves' proper, of Early Turonian age (see Fig. 5). 


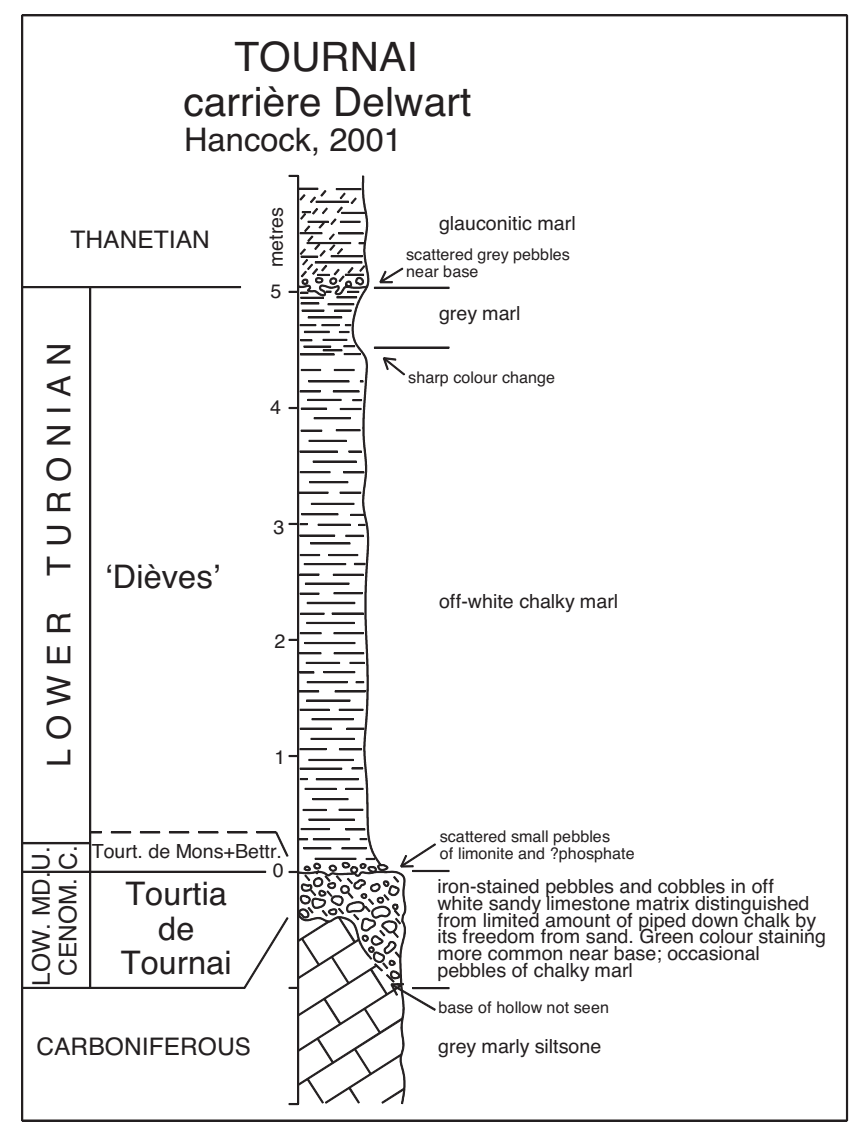

Fig. 4. Section of Delwart old quarry, $2 \mathrm{~km}$ south/southeast of Tournai (after fieldnotes by Hancock, 2001).
Tourtia de Tournai (Chercq, Hainaut, southern Belgium) The ammonites from this locality are predominantly preserved as creamy-buff internal moulds in micritic limestone with scattered quartz, glauconite and limonite grains, some with a light limonitic coating, one with patches of limonitised shell. The assemblage is: Schloenbachia varians, Sch. coupei, Sci. baculoides, Sci. roto and Scaphites sp. An interval from the Lower Cenomanian Mantelliceras mantelli Zone (i.e., Sch. varians and Sci. roto) to the lower, Turrilites costatus Subzone of the lower Middle Cenomanian Acanthoceras rhotomagense Zone (i.e., Sch. coupei and Sci. baculoides) is indicated.

Tourtia de Montignies-sur-Roc (Hainaut, southern Belgium) In limonitic preservation are found Schloenbachia varians, Sch. coupei, M. mantelli, Sci. baculoides and Scaphites sp. juv., while in creamy-buff micritic limestone are Sch. varians and Sci. roto. The assemblage possibly indicates horizons between the Lower Cenomanian Mantelliceras mantelli Zone to the Turrilites costatus Subzone of the lower Middle Cenomanian Acanthoceras rhotomagense Zone. However, in view of the fact that there is no current evidence that the Sharpeiceras schlueteri and Mantelliceras saxbii subzones extend beyond the Boulonnais and Pernes-en-Artois, the sole well-identified Lower Cenomanian zone around the Mons Basin is the Mantelliceras dixoni Zone, which has been demonstrated at Loffre, Hautrage, Onnaing and Sassegnies (Figs 1, 6-8). This is why we consider Sch. varians, $M$. mantelli and Sci. roto from Montignies-sur-Roc to be more probably indicative of the Mantelliceras dixoni Zone.

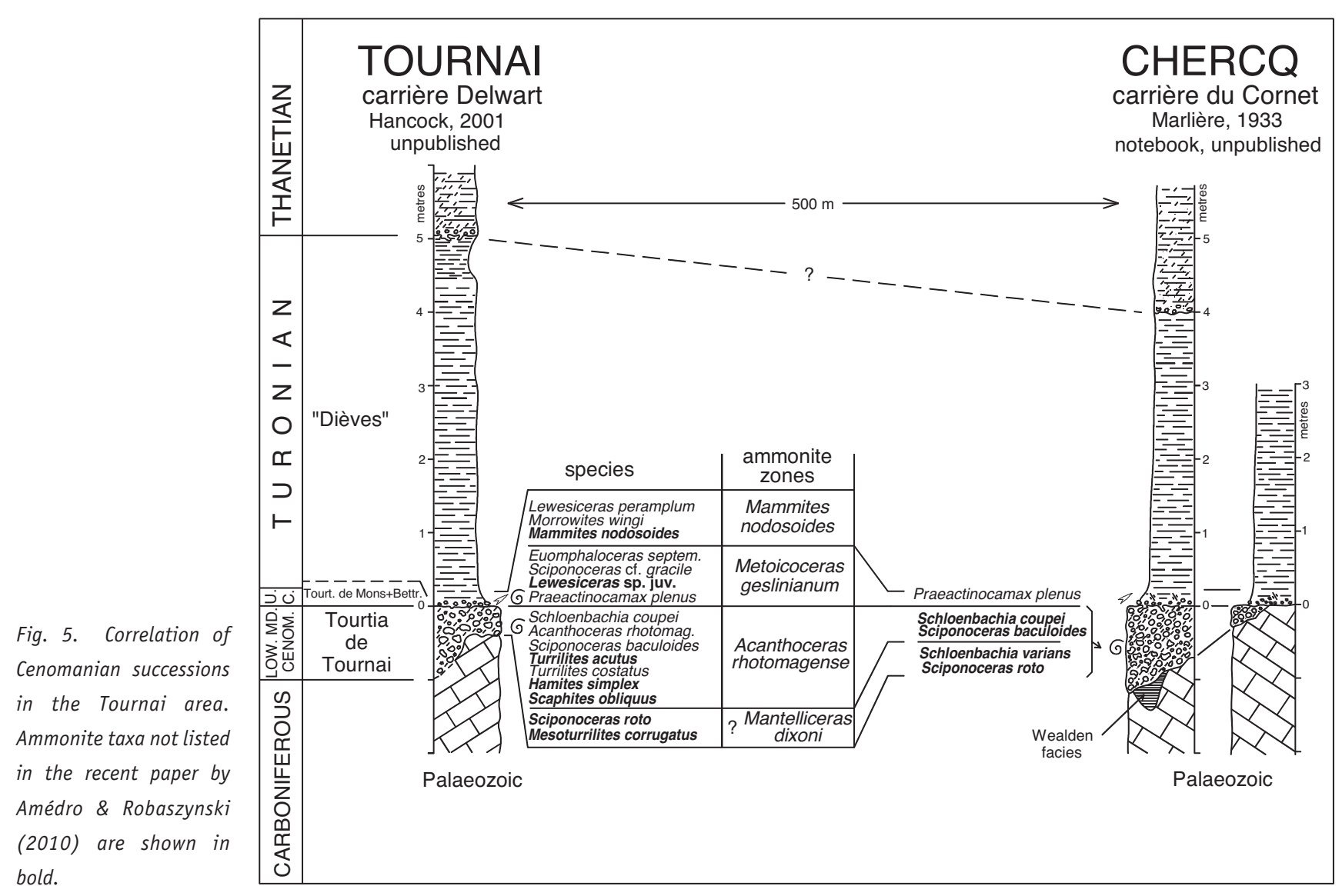




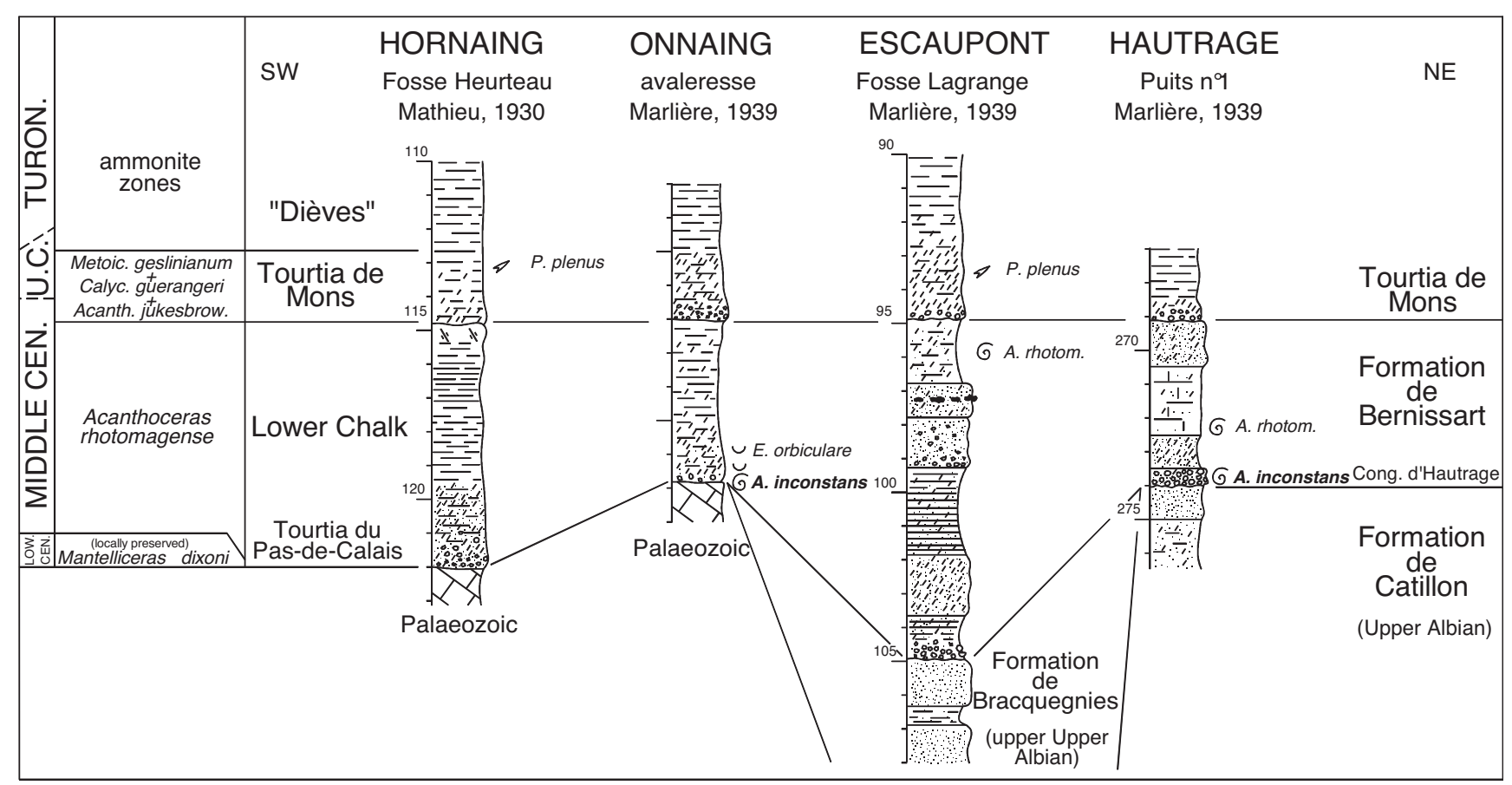

Fig. 6. Correlation of Cenomanian successions in the Valenciennes area (Hornaing, Onnaing) and the Mons Basin (Escaupont, Hautrage). Ammonite taxa not listed in the recent paper by Amédro \& Robaszynski (2010) are shown in bold.

Tourtia de Sassegnies (Sassegnies, northern France) Acompsoceras renevieri and $A$. inconstans are preserved as slightly deformed, pale grey to beige internal moulds of rather coarse-grained, glauconitic calcarenite. These species of Acompsoceras range throughout the Lower Cenomanian in western Europe, and are commonest in the Mantelliceras dixoni Zone. In fact, in the MHNL collections, Amédro \& Robaszynski (2010, pl. 3, fig. 4; pl. 4, fig. 2) noted A. renevieri and M. dixoni from the Tourtia de Sassegnies, thus confirming the Mantelliceras dixoni Zone age for the present material.

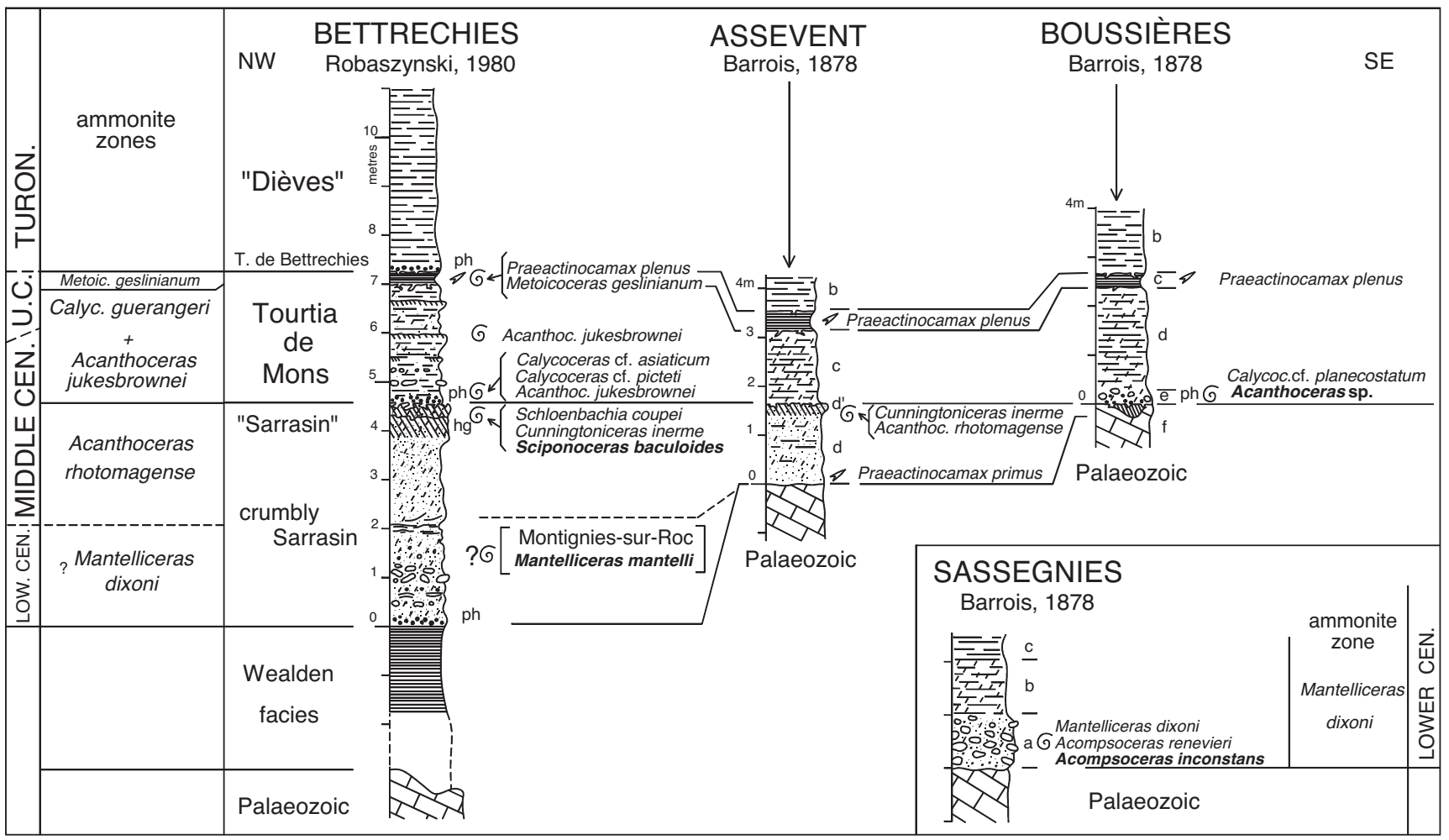

Fig. 7. Correlation of Cenomanian successions in the Maubeuge area (Bettrechies, Assevent, Boussières, Sassegnies). Ammonite taxa not listed in the recent paper by Amédro \& Robaszynski (2010) are shown in bold. 

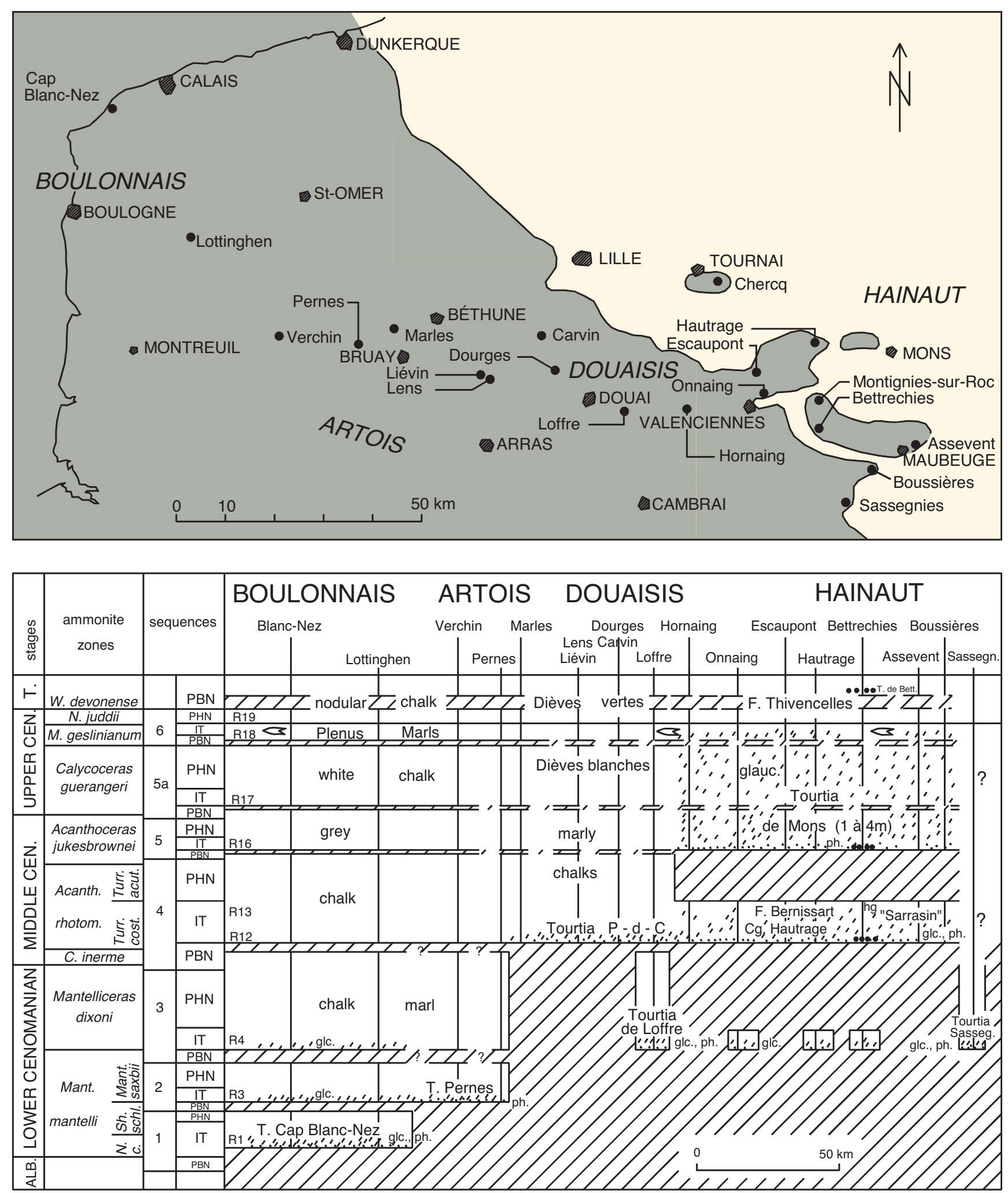

Fig. 8. Development of sequences and systems tracts in northern France and southern Belgium with the position of tourtias (modified from Amédro \& Robaszynski, 2010).

Meule de Bernissart (Hautrage, Onnaing, northern France) Acompsoceras inconstans of Early Cenomanian, probably Mantelliceras dixoni Zone, age, and probably originating from the 'Conglomérat d'Hautrage' (Formation de Bernissart).
Tourtia de Mons (Boussières-sur-Sambre, near Hautmont, northern France) - Phosphatised (and remanié?) fragments of Acanthoceras sp., of Middle Cenomanian age. 
Craie de Maisières (Thieu, Hainaut, southern Belgium) Lewesiceras cf. mantelli, preserved in a fine-grained, glauconitic calcarenite. Here considered to be of Late Turonian age, as this level also contains large fragmentary shells of Inoceramus mantelli.

Marne Grise ('Dièves') (Autreppe, Hainaut, southern Belgium) - Mammites nodosoides and Fagesia sp., preserved as black phosphate. Both are of Early Turonian, Mammites nodosoides Zone, age (see also remarks above under 'Tourtia de Tournai').

Dièves (Anderlues, Hainaut, southern Belgium) Collignoniceras woollgari regulare of Middle Turonian, Collignoniceras woollgari Zone, C. w. regulare Subzone, age.

\section{Repositories of specimens}

BGS.GSM: collections of the Geological Survey and Museum, currently housed at the British Geological Survey, Keyworth, Nottinghamshire, England; BMNH: The Natural History Museum, London (formerly British Museum of Natural History); EMP: École des Mines collections, Paris, now housed in the Université Claude Bernard, Lyon; IRScNB: Institut Royal des Sciences Naturelles de Belgique, Brussels; NHMW: Naturhistorisches Museum Wien, Vienna; OUM: Oxford University Museum of Natural History, 0xford, England; PIB: Paläontologisches Institut, Universität Bonn; RE: Ruhrland Museum, Essen.

\section{Conventions}

Dimensions are given in millimetres: $\mathrm{D}=$ diameter; $\mathrm{Wb}=$ whorl breadth; $\mathrm{Wh}=$ whorl height; $\mathrm{U}=$ umbilicus; $\mathrm{c}=$ costal dimension; ic $=$ intercostal dimension. Figures in parentheses are dimensions as a percentage of the diameter. Suture terminology is that of Korn et al. (2003): $\mathrm{E}=$ external lobe; $\mathrm{A}=$ adventive lobe (= lateral lobe (L) of Kullmann \& Wiedmann, 1970); U = umbilical lobe; $\mathrm{I}=$ internal lobe.

\section{Systematic palaeontology}

Order Ammonoidea von Zittel, 1884

Suborder Ammonitina Hyatt, 1889

Superfamily Desmoceratoidea von Zittel, 1895

Family Pachydiscidae Spath, 1922

Genus Lewesiceras Spath, 1939

\section{Type species}

Ammonites peramplus Mantell, 1822, p. 200, by original designation (Spath, 1939, p. 296).

Lewesiceras sp. juv.

\section{Material}

IRScNB 11439 and IRScNB 11440, both labelled as coming from the 'Tourtia de Tournai' at Tournai (Hainaut), we rather consider these to have come from a higher level, e.g. the Tourtia de Mons, of latest Cenomanian age (see previous; Fig. 5).

\section{Description}

IRScNB 11439 (Fig. 9D-F, I-K) is a black phosphatised internal mould of a phragmocone, $28.3 \mathrm{~mm}$ in diameter, with patches of phosphatised shell and traces of brown limonitic encrustation. Coiling is moderately evolute, the umbilicus comprising an estimated 32 per cent of the diameter, the umbilical wall broadly rounded, the intercostal section depressed reniform, the costal section depressed polygonal, with the greatest breadth at the umbilical bullae. There are four strong umbilical bullae on the adapertural half whorl. They give rise to pairs of strong concave ribs that sweep forwards over the ventrolateral shoulder and cross the venter in a broad convexity. A single intercalated rib is present between the paired ribs at one point, while there are up to three weaker intercalated ribs (some incipiently bifurcate) that arise both low and high on the flank, and follow a course parallel to the primaries; they are most conspicuously developed on the ventrolateral shoulders and venter. At one point, the ventral development of the ribs becomes chevron-like, possibly the result of a short-term pathological condition. IRScNB 11440 (Fig. 9G, H, L, M) is a black phosphatised internal mould of a $90^{\circ}$ sector of phragmocone fragment with a maximum preserved whorl height of $12.2 \mathrm{~mm}$ and a costal whorl breadth to height ratio of 1.16 . There are two well-preserved bullae on the fragment that give rise to pairs of ribs, with four long or short ribs (some incipiently bifurcate) intercalated between successive pairs of bullate ribs. Interspaces adjacent to the primary ribs may be deepened into constrictions, as in the previous specimen. The suture is moderately incised, with symmetrically bifid E/A and A/U2 and trifid A.

\section{Discussion}

These two specimens are reminiscent of the holotype of $L$. cenomanense Wiedmann \& Schneider, 1979 (p. 667, text-fig. 9a, b; pl. 9, fig. 6; see also Kaplan et al., 1998, p. 86, pl. 17, figs 1-3), although the bifurcation of the intercalated ribs is less pronounced. The present specimens differ from the Early Cenomanian Lewesiceras wiedmanni Wright \& Kennedy, 1984 (p. 63, pl. 4, fig. 3) in the coarser ribbing, with only a single intercalated rib between successive pairs of primaries. Lewesiceras mantelli Wright \& Wright, 1951 (p. 20) of comparable size have single primary ribs succeeded by strong constrictions, and coarse intercalated ribs that do not show incipient branching.

Fig. 9D-M. 


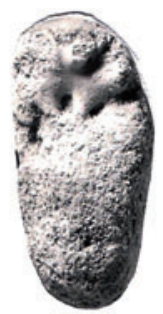

A

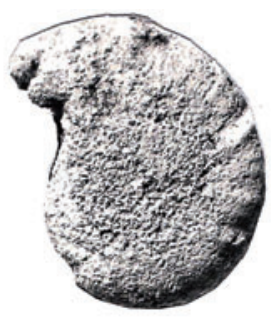

B
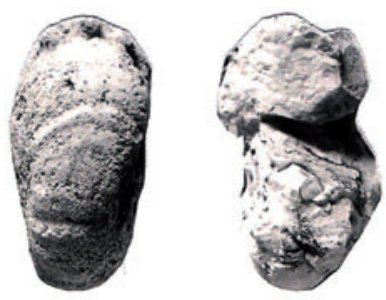

D

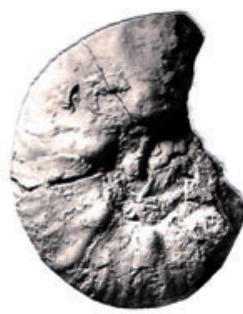

E

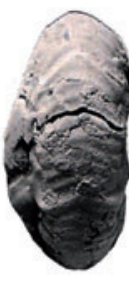

F

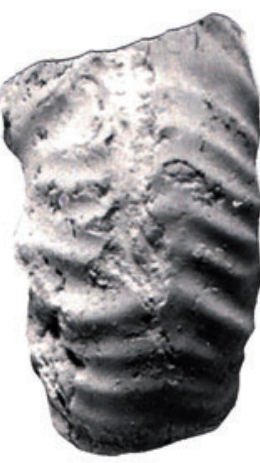

$L$
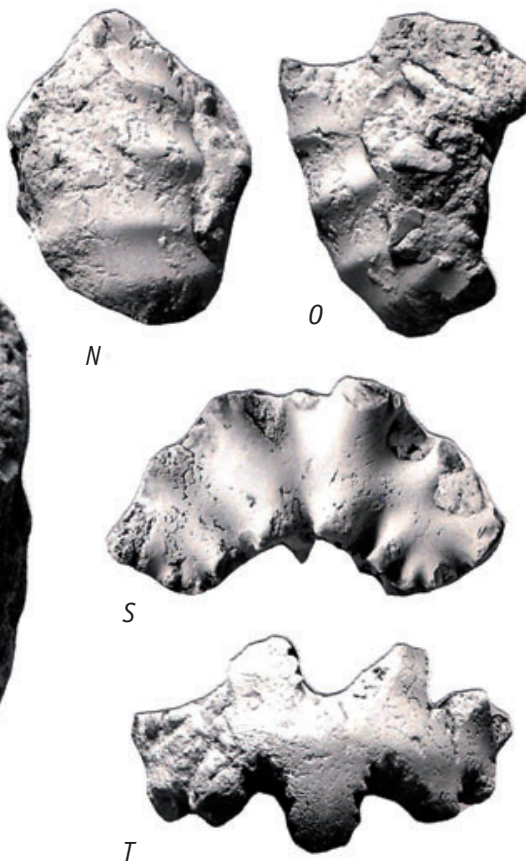

Fig. 9A-C, P-R. Lewesiceras Cf. mantelli Wright \& Wright, 1951, IRScNB 11438, Craie de Maisières, Thieu (Hainaut); D-M. Lewesiceras sp. juv., D-F, I-K are IRSCNB 11439; G-H, L-M are IRSCNB 11440, Tourtia de Tournai, Tournai (Hainaut); N, 0. ?Lewesiceras sp., IRSCNB 11441, Tourtia de Tournai, Tournai (Hainaut); S, T. Fagesia sp., IRSCNB 11442, Marne Grise, Autreppe (Hainaut). A-H, N-O and S-T are $\times 1 ; I-M$ and P-R are $\times 2$.

\section{Occurrence}

Labelled as 'Tourtia de Tournai', but more probably originating from the Tourtia de Mons, of Late Cenomanian (Metoicoceras geslinianum Zone) age, or from an even higher level, and therefore, for the time being, best left in open nomenclature.

\section{Lewesiceras cf. mantelli Wright \& Wright, 1951}

Fig. 9A-C, P-R.

\section{Compare:}

1951 Lewesiceras mantelli Wright \& Wright, p. 20.

1979 Lewesiceras mantelli Wright \& Wright; Wright, p. 310, pl. 4, figs 1-3; pl. 6, figs 4, 5 (with synonymy).

Type

The holotype, by original designation, is BMNH 88587, the original of Sharpe (1853, pl. 10, fig. 3), from Oldbury Hill (Wiltshire, England), presumably from the Upper Turonian (Subprionocyclus neptuni Zone) Chalk Rock. 


\section{Material}

IRScNB 11438, from the Craie de Maisières of Thieu, Hainaut.

\section{Description}

The specimen is a badly abraded internal mould $30 \mathrm{~mm}$ in diameter, preserved in a fine-grained glauconitic calcarenite. There are indications of the former presence of a further whorl or whorls. Coiling mode cannot be established. The whorl section is depressed reniform in intercostal section. Only the ventrolateral and ventral ornament is preserved. There are three strong primary ribs on the adapertural half whorl that are prorsiradiate and feebly concave on the ventrolateral shoulders and feebly convex on the venter. They are succeeded by a prominent constriction. There are traces of intercalated ribs between successive primaries, but their exact number cannot be established.

\section{Discussion}

Although poorly preserved, the pattern of primary ribbing and constrictions on this specimen suggest these to be Lewesiceras mantelli, although reference to L. peramplum (Mantell, 1822) (see revision in Wright \& Kennedy, 1981, p. 29, text-figs 9-12; pl. 2, figs 1-3; pl. 3) cannot be excluded, hence the qualified interpretation.

\section{Occurrence}

The present specimen can be dated no more precisely than Turonian. Lewesiceras mantelli is known from the upper Middle and Upper Turonian of southern England, northern and southeast France, Germany, the Czech Republic and Ukraine.

\section{Superfamily Hoplitoidea H. Douvillé, 1890}

Genus Schloenbachia Neumayr, 1875

\section{Type species}

Ammonites varians J. Sowerby, 1817, p. 169, pl. 176, by the subsequent designation of H. Douvillé (1890, p. 290).

\section{Discussion}

Schloenbachia is by far the commonest ammonite in all tourtias predating the Tourtia de Mons, as e.g. the Tourtia de Tournai and the Tourtia de Montignies-sur-Roc, with more than thirty specimens seen. As discussed previously (see e.g., Juignet \& Kennedy, 1976; Kennedy et al., 1979, 2008; Thomel, 1992; Kaplan et al., 1998; Gale et al., 1999; Wilmsen \& Mosavinia, 2011), study of large populations of Schloenbachia from any given horizon reveals wide, continuous intraspecific variation in juveniles and phragmocones from near-smooth to hypernodose individuals. Both large and small adults occur at any given horizon, indicating the presence of size-related dimorphism. There is also a change in ornament, and the proportion of variants through time. As a result, it is possible to identify the horizon of assemblages, and, in some cases individual specimens. The most obvious changes are the presence/absence and strength of umbilical tubercles and the proportion of inflated individuals, which increase through the Lower and lower Middle Cenomanian, and adult size, which decreases markedly from lower Middle to upper Middle and Upper Cenomanian.

On this basis, Schloenbachia varians (J. Sowerby, 1817) from the Lower Cenomanian Mantelliceras mantelli Zone can be divided into a series of integrating 'formae' (Kennedy et al., 2008, p. 129) from compressed individuals, forma subplana (Mantell, 1822), forma tollotiana (Pictet, 1847), forma subtuberculata Sharpe, 1853, forma tetrammata J. de C. Sowerby, 1828, and varians sensu stricto, to the hypernodose forma ventriosa Stieler, 1922.

Schloenbachia from the lower Middle Cenomanian Acanthoceras rhotomagense Zone are referred to a variable Schloenbachia coupei (Brongniart, 1822), divided into formae that range from compressed and feebly ornamented forma costata Sharpe, 1853, various as yet un-named morphotypes to forma quadrata Spath, 1926a, coupei sensu stricto, trituberculata Spath, 1926a, to an unnamed hypernodose variant.

Many of these formae are present in the higher parts of the upper Lower Cenomanian Mantelliceras dixoni Zone, and it is not readily possible to distinguish between assemblages from high in the dixoni Zone and those from the Turrilites costatus Subzone of the Acanthoceras rhotomagense Zone.

The Late Cenomanian Schloenbachia lymensis Spath, 1926a is highly distinctive, and characterised by very small adult size in additional to details of ornament.

A few of the ammonites from the tourtias, apart from Schloenbachia, indicate the presence of the Lower Cenomanian. Rather more individuals indicate the lower Middle Cenomanian Acanthoceras rhotomagense Zone, Turrilites costatus Subzone, and a single T. acutus Passy, 1832, is indicative of the succeeding Turrilites acutus Subzone. There are no ammonite indicators of the upper Middle or Upper Cenomanian in the fauna. It is thus unsurprising that the numerically dominant Schloenbachia indicate a range of horizons. Those referred to Schloenbachia varians indicate the lower Lower Cenomanian Mantelliceras mantelli to Mantelliceras dixoni zones. The majority of individuals are referred either to Schloenbachia coupei, or transitions between this and Sch. varians, and indicate an interval spanning the upper part of the upper Lower Cenomanian Mantelliceras dixoni Zone to the Turrilites costatus Subzone of the lower Middle Cenomanian Acanthoceras rhotomagense Zone.

Schloenbachia varians (J. Sowerby, 1817)

Figs 10E, F, S-X, 11L-0, Q-T.

1817 Ammonites varians J. Sowerby, p. 169 (pars), p. 176 uppermost figure, figure in row below, right-hand figure in row below.

1822 Ammonites varians var. subplana Mantell, p. 166, pl. 21, fig. 2. 
1822 Ammonites varians var. intermedia Mantell, p. 166, pl. 21, figs 5, 7 .

1828 Ammonites varians var. tetrammata J. de C. Sowerby, p. 166 , pl. 587, fig. 2 .

1847 Ammonites tollotianus Pictet, p. 109, pl. 10, fig. 5.

1853 Ammonites varians var. subtuberculata Sharpe, p. 22, pl. 8, figs 5, 6 .

1853 Ammonites varians var. intermedia Sharpe, p. 23, pl. 8, fig. 7 (non Mantell = Sch. subvarians Spath, 1926b).

1853 Ammonites coupei var. inflata Sharpe, p. 24, pl. 8, fig. 1 (= Sch. ventriosa Stieler, 1922).

1871 Ammonites varians Sowerby; Schlüter, p. 10 (pars), pl. 4, figs 1-19, 21 only (non fig. $20=$ Sch. coupei).

1922 Schloenbachia ventriosa Stieler, p. 31.

1926a Schloenbachia subvarians Spath, p. 430.

1926a Schloenbachia subvarians aperta Spath, p. 430.

1926a Schloenbachia subvarians densicostata Spath, p. 430.

1926b Schloenbachia subvarians Spath, p. 81.

1928 Schloenbachia ecarinata Spath, p. 241.

1998 Schloenbachia varians (J. Sowerby, 1817); Kaplan et al., p. 107, pl. 10, fig. 12; pl. 11, fig. 5; pl. 12, figs 1-4, 6, 9-12; pl. 13, figs $3-5,13,14$; pl. 14, figs $1-21$; pl. 15 , figs 1-13; pl. 16, figs 1-14 (with additional synonymy).

1999 Schloenbachia varians (J. Sowerby, 1817); Gale et al., pl. 1, figs 1, 2, 12-15.

2008 Schloenbachia varians (J. Sowerby, 1817); Kennedy et al., p. 129, pl. 5, figs 10-12, 14, 15; pl. 6, figs 3, 6-13.

\section{Type}

Lectotype, by the subsequent designation of Spath (1938, p. 544), is BMNH 43962b, the original of J. Sowerby (1817, pl. 176, top figure), from the Lower Chalk at an unknown locality in southern England.

\section{Material}

EMP335b and IRScNB 11450, from the Tourtia de Montigniessur-Roc, Hainaut; IRScNB 11451, IRScNB 11453 and IRSNB 11479, all from the Tourtia de Tournai of Tournai, Hainaut; IRScNB 11452, IRScNB 11456 and IRScNB 11457, all from from the Tourtia de Tournai of Chercq, Hainaut; IRScNB 11482, from the Tourtia de Tournai of Hautrage, Hainaut.

\section{Discussion}

Amongst specimens referred to Sch. varians of the Mantelliceras mantelli Zone, forma tollotiana is well represented by individuals such as EMP 335b (Fig. 11L-0), IRScNB 11479 (Fig. 11S, T), IRScNB 11457 (Fig. 11Q-R) and IRScNB 11482 (not illustrated). In these compressed individuals the umbilical bullae are very weak to obsolete, the inner lateral tubercles stronger, but still tiny. They give rise to pairs of narrow flexuous ribs, with additional ribs intercalated between, the ribs convex on the inner flank, concave on the outer flank, and sweeping forwards to link to tiny ventral clavi. IRScNB 11451 (Fig. 10S-U) is a transitional individual between forma tollotiana and forma subtuberculata, the latter represented by IRScNB 11452 (Fig. 10V, W). These specimens have very weak umbilical bullae, and stronger inner lateral tubercles. The rib pattern is more complex than in forma tollotiana. The ribs that arise from the lateral tubercles link to strong oblique ventral clavi. They are accompanied by intercalated ribs that are restricted to the outer flank, and are not linked to either an inner lateral or a ventrolateral tubercle.

Individuals such as IRScNB 11453 (Fig. 10X), IRScNB 11455 (Fig. 11K) and IRScNB 11456 (Fig. 11P) have the ribbing style of forma tollotiana combined with umbilical bullae that are only slightly weaker than, or equal in strength to, the lateral tubercle, suggesting a higher horizon in the Lower Cenomanian, possibly as high as the Mantelliceras dixoni Zone.

IRScNB 11450 (Fig. 10E, F) is a robustly ornamented fragment with strong inner lateral and more numerous ventrolateral tubercles, linked by low blunt ribs, and thus close to varians sensu stricto.

\section{Occurrence}

Lower Cenomanian of Northern Ireland, England, southern Belgium, France, Germany, Denmark (Bornholm), Switzerland, Poland, Ukraine, Kazakhstan, Turkmenistan, Iran and Greenland.

\section{Schloenbachia coupei (Brongniart, 1822)}

Figs 10A-D, G-R, 11D-J, U-Z.

1822 Ammonites coupei Brongniart, pl. N, fig. 3, 3a.

1851-1852 Ammonites(?) coupei Brongniart; Bronn, p. 317, pl. 33, fig. 4 (=Sch. quadrata Spath, 1926a).

1851-1852 Ammonites varians Sowerby; Bronn, p. 317, pl. 33, fig. 2 (non Sowerby; = Sch. nodulosa Stieler, 1922).

1853 Ammonites varians var. costata Sharpe, p. 23, pl. 8, fig. 9.

1853 Ammonites coupei var. tuberculata Mantell; Sharpe, p. 23, pl. 8, fig. 4 (non Mantell, = Sch. trituberculata Spath, 1926a).

1885 Schloenbachia coupei (Brongniart); Noetling; p. 236, pl. 8, fig. 1, 1a (= Sch. atava Spath, 1926a).

1885 Schloenbachia coupei (Brongniart); Noetling; p. 236, pl. 8, fig. 1 (= Sch. devonensis Spath, 1926a).

1922 Schloenbachia nodulosa Stieler, p. 32.

1926a Schloenbachia trituberculata Spath, p. 430.

1926a Schloenbachia atava Spath, p. 430.

1926a Schloenbachia devonensis Spath, p. 430.

1926a Schloenbachia quadrata Spath, pp. 426, 430.

1938 Schloenbachia costata (Sharpe); Spath, p. 546.

1976 Schloenbachia coupei (Brongniart); Juignet \& Kennedy, p. 78, pl. 8, figs 4, 8-13; pl. 9, figs 1-9.

1998 Schloenbachia coupei (Brongniart, 1822); Kaplan et al., p. 108, pl. 12, figs 5, 7, 12, 14, 15; pl. 18, figs 4, 8 (with additional synonymy). 


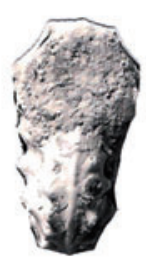

A

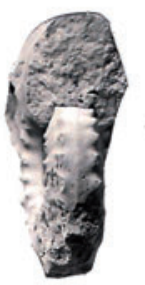

G

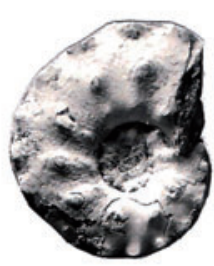

B

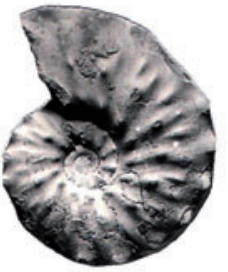

H

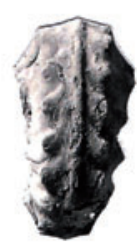

c

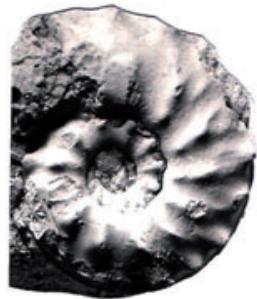

D
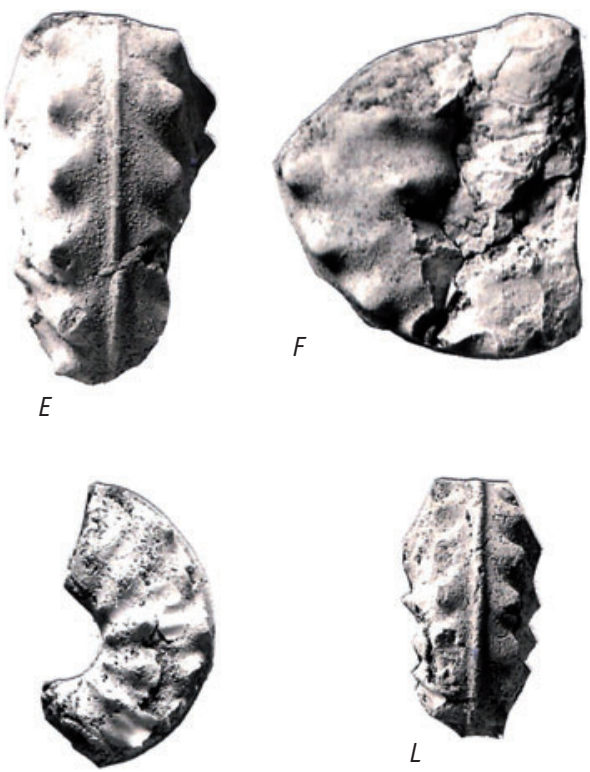

I

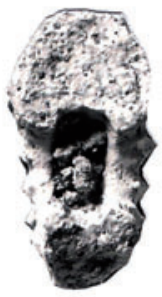

J

K
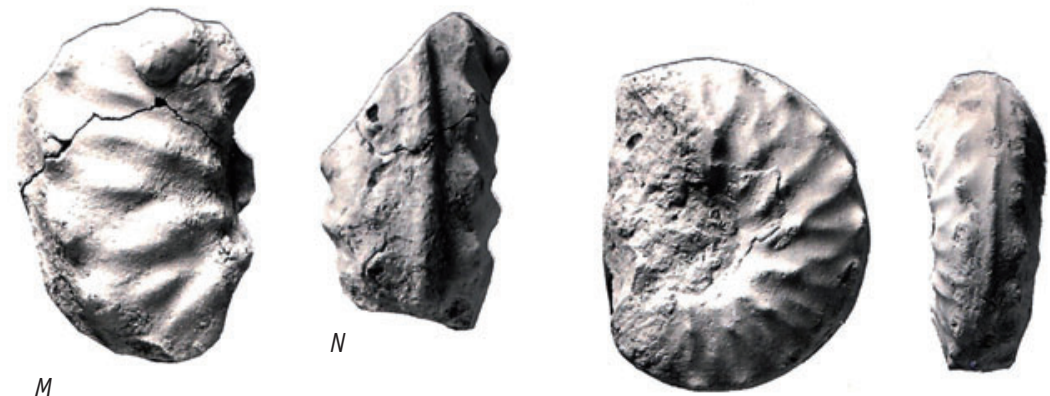

P
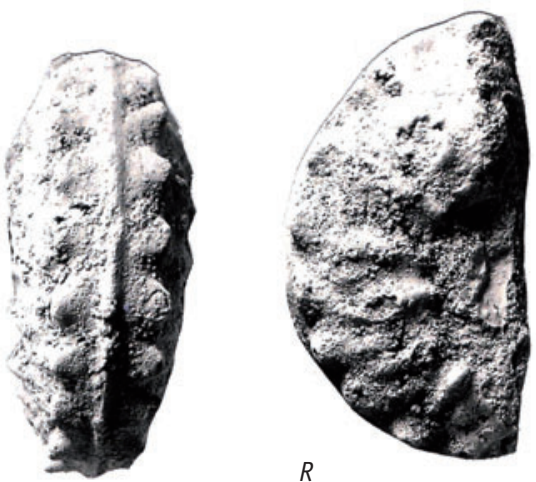

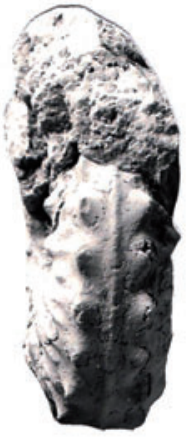

S

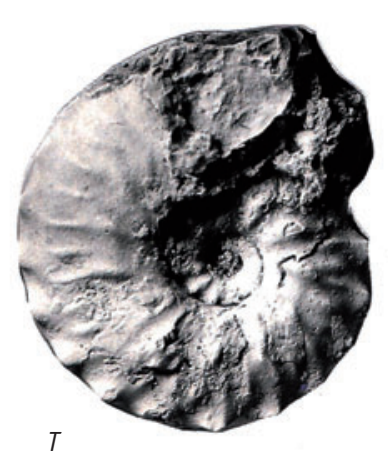

T

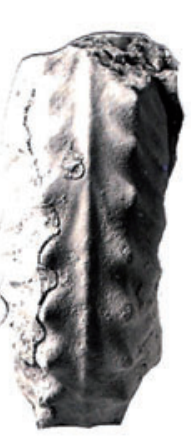

U

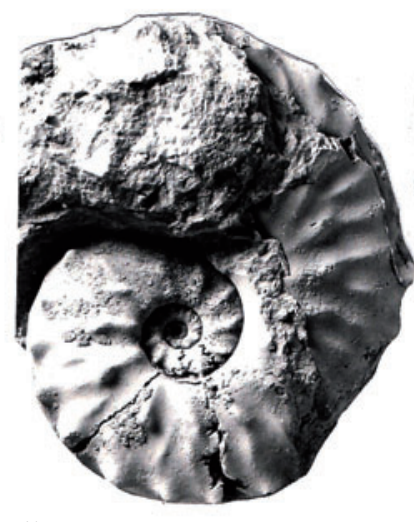

V
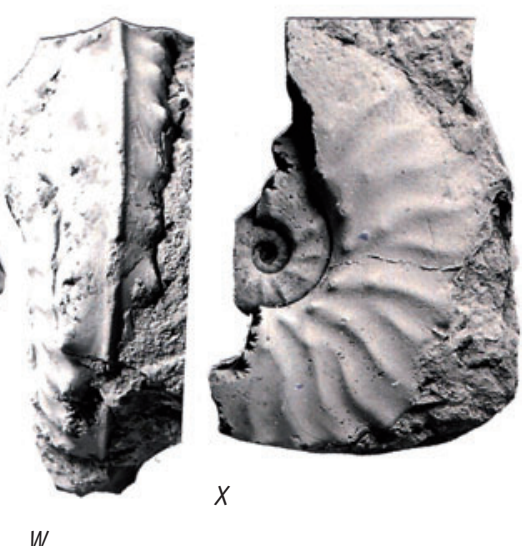

$x$ 


\section{Types}

Brongniart's types, from the Middle Cenomanian of Rouen (SeineMaritime, France) and in the Sorbonne Collections, are currently housed in the Universite Pierre et Marie Curie, Paris VI.

\section{Material}

IRScNB 11448, from the Tourtia de Tournai of Chercq, Hainaut; IRSCNB 11443, IRScNB 11445, IRScNB 11446, IRScNB 11449, IRScNB 11454, NHMW 1858 XX 5 and NHMW c.541, all from the Tourtia de Tournai of Tournai, Hainaut; EMP335a (ex Chaper Colln.) and IRScNB 11444, both from the Tourtia de Montigniessur-Roc, Hainaut.

\section{Discussion}

Among individuals referred to Sch. coupei are variants with well-developed umbilical, inner lateral and ventral tubercles, the inner lateral and ventral tubercles linked by zigzag and incipiently looped ribs as in forma nodulosa: IRScNB 11448 (Fig. 100, P), IRScNB 11445 (Fig. 10G-I) and IRScNB 11449 (Fig. 10Q, R). A more compressed and feebly ribbed variant, to a degree transitional to forma costata is represented by IRScNB 11454 (Fig. 11H-J). Stouter, more robustly ornamented, individuals have well-developed umbilical, inner lateral and ventral tubercles, as well as coarse ribs, and are represented by specimens such as NHMW $1858 \mathrm{XX} 5$ (Fig. 11U-W), IRScNB 11447 (Fig. 10M, N), IRScNB 11446 (Fig. 10J-L) and IRScNB 11444 (Fig. 10D), and are variants around coupei sensu stricto. With increasing inflation, strengthening tuberculation and loss of ribs, forma trituberculata is approached, as represented by IRScNB 11443 (Fig. 10A-C).

These specimens, referred to $S$. coupei, indicate a horizon no higher than the lower Turrilites costatus Subzone of the Acanthoceras rhotomagense Zone, and some find a match in individuals from as low as the upper Lower Cenomanian Mantelliceras dixoni Zone.

\section{Occurrence}

Middle Cenomanian; the transition to Sch. varians takes place in the upper Lower Cenomanian Mantelliceras dixoni Zone. The geographic range extends from England, to southern Belgium, France (Pas-de-Calais to Alpes-Maritimes), Germany, Switzerland, Poland, to as far east as Khrebet Pay-Koy on the Kara Sea coast, and as far southeast as the Ukraine, the Mangyshlak Peninsula (Kazakhstan), Kopet Dagh (Turkmenistan) and Iran.

Superfamily Acanthoceratoidea De Grossouvre, 1894

Family Acanthoceratidae De Grossouvre, 1894

Subfamily Mantelliceratinae Hyatt, 1903

Genus Mantelliceras Hyatt, 1903

\section{Type species}

Ammonites mantelli J. Sowerby, 1814, p. 199 (ICZN Specific Name no. 1634).
Mantelliceras mantelli (J. Sowerby, 1814)

Fig. 11A-C.

1814 Ammonites mantelli J. Sowerby, p. 119, pl. 55, lower figure only.

1984 Mantelliceras mantelli (J. Sowerby, 1814); Wright \& Kennedy, p. 99, pl. 16, fig. 5; pl. 17, figs 1, 3; pl. 18, figs 1-3; pl. 19, figs 1-6; pl. 21, figs 2, 4; pl. 24, fig. 3; pl. 36, fig. 1; text-figs 20a-d, 26a, c, e (with full synonymy).

1998 Mantelliceras mantelli (J. Sowerby, 1814); Kaplan et al., p. 115 , pl. 11, figs 1,2 ; pl. 17, figs 12,13 ; pl. 19, figs $1-9$; pl. 22, figs 3, 4; pl. 23, fig. 8; pl. 24, figs 4-6; pl. 25, figs $1-5$ (with additional synonymy).

\section{Type}

Lectotype, by the subsequent designation of Kennedy (1971, p. 52), is BMNH 43940a from the Lower Cenomanian Chalk Marl of Ringmer near Lewes (Sussex, England), the original of J. Sowerby (1814, pl. 55, lower figure only), reillustrated by Wright \& Kennedy (1984, pl. 18, fig. 3a-c).

\section{Material}

An unregistered specimen in the EMP Collections (ex Deshayes Collection), from 'St Roc, Montignies', presumably Montigniessur-Roc, Hainaut.

\begin{tabular}{lllll}
\multicolumn{2}{l}{ Dimensions } \\
\begin{tabular}{lllll}
\hline D & Wb & Wh & Wb:Wh & U \\
\hline $37.8(100)$ & $-(-)$ & $17.3(45.8)$ & - & $10(26.5)$ \\
\hline
\end{tabular}
\end{tabular}

\section{Description}

The specimen is a juvenile with a $90^{\circ}$ sector of body chamber, and replaced, limonitised shell material. Coiling is moderately involute, the umbilicus comprising 26.5 per cent of the diameter, of moderate depth, with a flattened, subvertical wall and narrowly rounded umbilical shoulder. The whorl section is slightly compressed and octagonal in costal section. There are eight umbilical bullae on the $240^{\circ}$ sector of outer whorl preserved. These increase markedly in strength as size increases. The bullae give rise to single straight, prorsiradiate primary ribs; there are also occasional non-bullate primaries, and one or two shorter intercalated ribs between successive primaries; these arise both high and low on the flanks, to give a total of 24 ribs per whorl at the ventrolateral shoulder. The bullate primary ribs bear a small lateral tubercle, and all ribs bear a small, conical inner, and a stronger outer ventrolateral tubercle, the latter connected over the venter by a relatively coarse transverse rib.

\section{Discussion}

Juveniles of $M$. mantelli are characterised by a polygonal whorl section with 32-40 ribs per whorl, alternating irregularly long and short. The long ribs have umbilical and lateral tubercles 

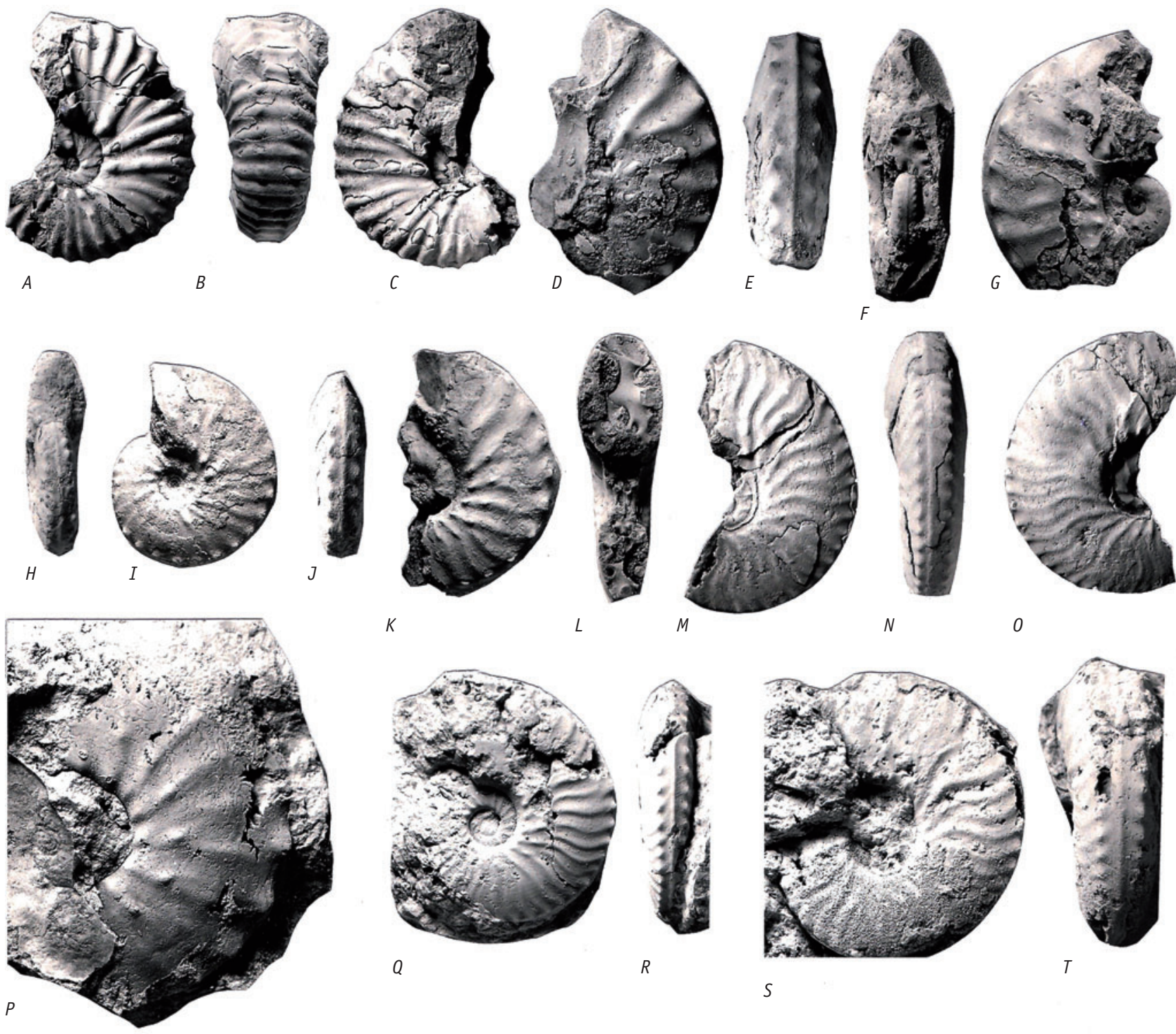

K
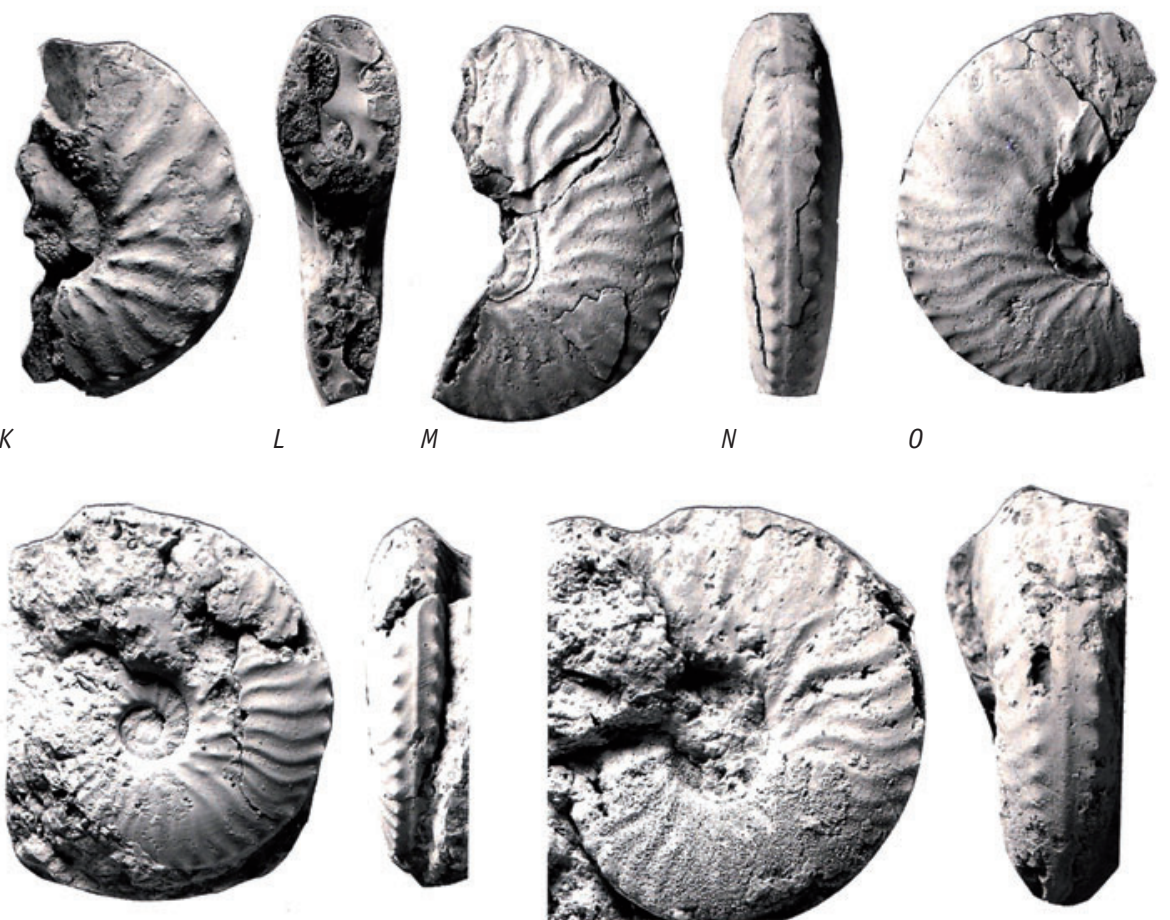

Q
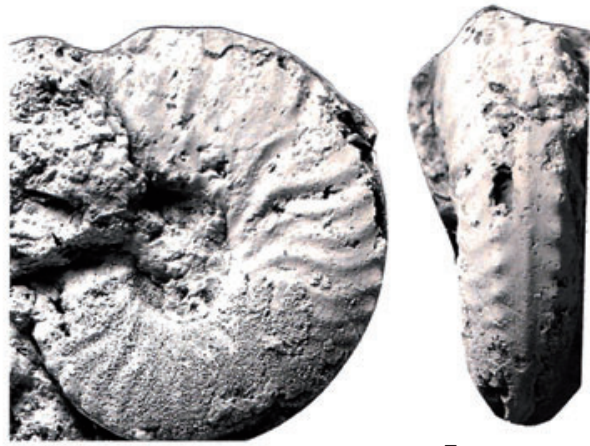

$S$

$T$
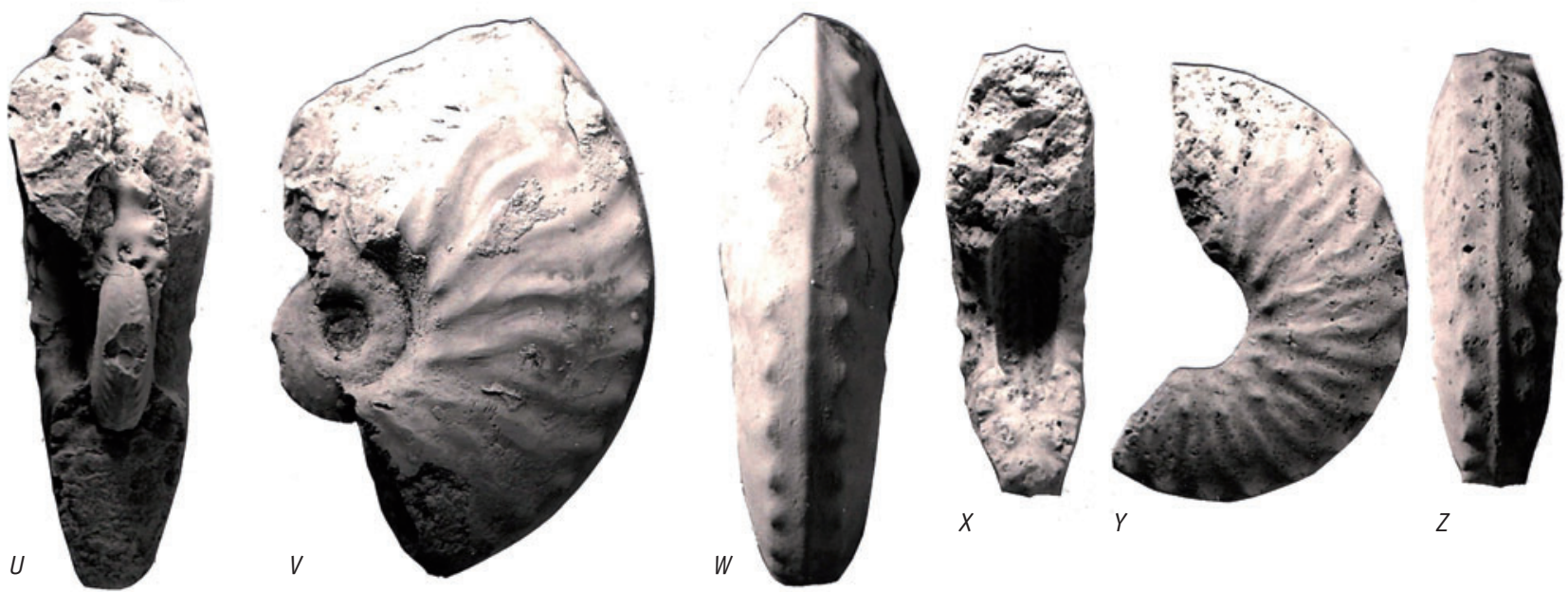

Fig. 11A-C. Mantelliceras mantelli (J. Sowerby, 1814), EMP unregistered (ex Deshayes Collection), Tourtia, presumably Montignies-sur-Roc (Hainaut); D-J, M, U-Z. Schloenbachia coupei (Brongniart, 1822), D-G are aff. forma tollotiana (EMP 335a, ex Chaper Collection), Tourtia, Montignies-sur-Roc (Hainaut); H-J are IRSCNB 11454, forma nodulosa, Tourtia de Tournai, Tournai (Hainaut); U-W are NHMW 1858 XX 5, all aff. forma tollotiana, all Tourtia de Tournai, Tournai (Hainaut); X-Z are NHMW C.5416, close to forma nodulosa, Tourtia de Tournai, Tournai (Hainaut); K-P, Q-T. Schloenbachia varians (J. Sowerby, 1817) forma tollotiana, $K$ is IRSCNB 11455; L-O are EMP335b (ex Chaper Collection), Tourtia, Montignies-sur-Roc (Hainaut); $P$ is IRSCNB 11456; $Q, R$ are IRSCNB 11457, Tourtia de Tournai, Chercq (Hainaut); S, T are IRSCNB 11479, Tourtia de Tournai, Tournai (Hainaut). All figures are $\times 1$. 
and inner and outer ventrolateral clavi. The short ribs all bear inner and outer ventrolaterals while a few of the longer ones have the lateral tubercle as well. Microconchs of the species are adult at $60 \mathrm{~mm}$; macroconchs are known to be up to $150 \mathrm{~mm}$ in diameter. Lateral and inner ventrolateral tubercles disappear on the adult body chamber, while the outer ventrolaterals decline or disappear to give a rounded venter.

Wright \& Kennedy (1984, p. 99) outlined the reasons for regarding the species and varieties listed in their synonymy as inseparable from $M$. mantelli. The species is easily distinguished from M. lymense (Spath, 1926a), M. couloni (d'Orbigny, 1850) and M. saxbii (Sharpe, 1857), which are generally compressed and typically lack lateral tubercles. Mantelliceras picteti Hyatt, 1903 has a similar style of ribbing and tuberculation but the whorl section is quadrate and compressed, with rather distant ribbing at maturity, while $M$. cantianum Spath, 1926a is very inflated with a whorl section that expands rapidly during development, has a broad venter with strong ribs and feeble outer ventrolateral tubercles, inner ventrolateral tubercles that are lost early in ontogeny and strong lateral tubercles linked to a weak umbilical bulla by a strong rib.

\section{Occurrence}

The species is commonest in the Mantelliceras mantelli Zone of the Lower Cenomanian and is only rarely found in the succeeding Mantelliceras dixoni Zone. Apart from the present record from Hainaut, the species ranges from England to Northern Ireland (a doubtful record), Westfalen (Germany), the Boulonnais, Haute-Normandie, Sarthe, Maine, Argonne, Isère and south to Cassis (Bouches-du-Rhône) in France, the remainder of western Europe, Russia, North Africa, KwaZulu (South Africa), Madagascar and southern India.
Subfamily Acanthoceratinae De Grossouvre, 1894 Genus Acompsoceras Hyatt, 1903

\section{Type species}

Ammonites bochumensis Schlüter, 1871, p. 1, pl. 1, figs 1-4, by original designation (Hyatt, 1903, p. 111) = Ammonites renevier Sharpe, 1857, p. 44, pl. 20, fig. 2.

\section{Acompsoceras renevieri (Sharpe, 1857)}

Fig. 12A-C.

1857 Ammonites Renevieri Sharpe, p. 44, pl. 20, fig. 2.

1871 Ammonites Bochumensis Schlüter, p. 1, pl. 1, figs 1-4; pl. 2, fig. 1.

1871 Ammonites Essendiensis Schlüter, p. 3, pl. 1, figs 5-7; pl. 2, fig. 2.

1987 Acompsoceras renevieri (Sharpe, 1857); Wright \& Kennedy, p. 140 , text-fig. 34g, 35d-f, 36a-f, 37-40, 43d, e; pl. 43, fig. 2 (with full synonymy).

1998 Acompsoceras renevieri (Sharpe, 1857); Kaplan et al., p. 136, pl. 10, figs 6, 7; pls 34-35; pl. 36, figs 1-3; pl. 37, figs 4-6; pl. 38; pl. 40; pl. 41, figs 1, 5 (with additional synonymy).

\section{Types}

The lectotype, designated by Wright \& Wright (1951, p. 38), is BGS.GSM 7753, from Blackdown (Isle of Wight, England), the original of Sharpe (1857, pl. 20, fig. 2); the paralectotypes have not been traced.

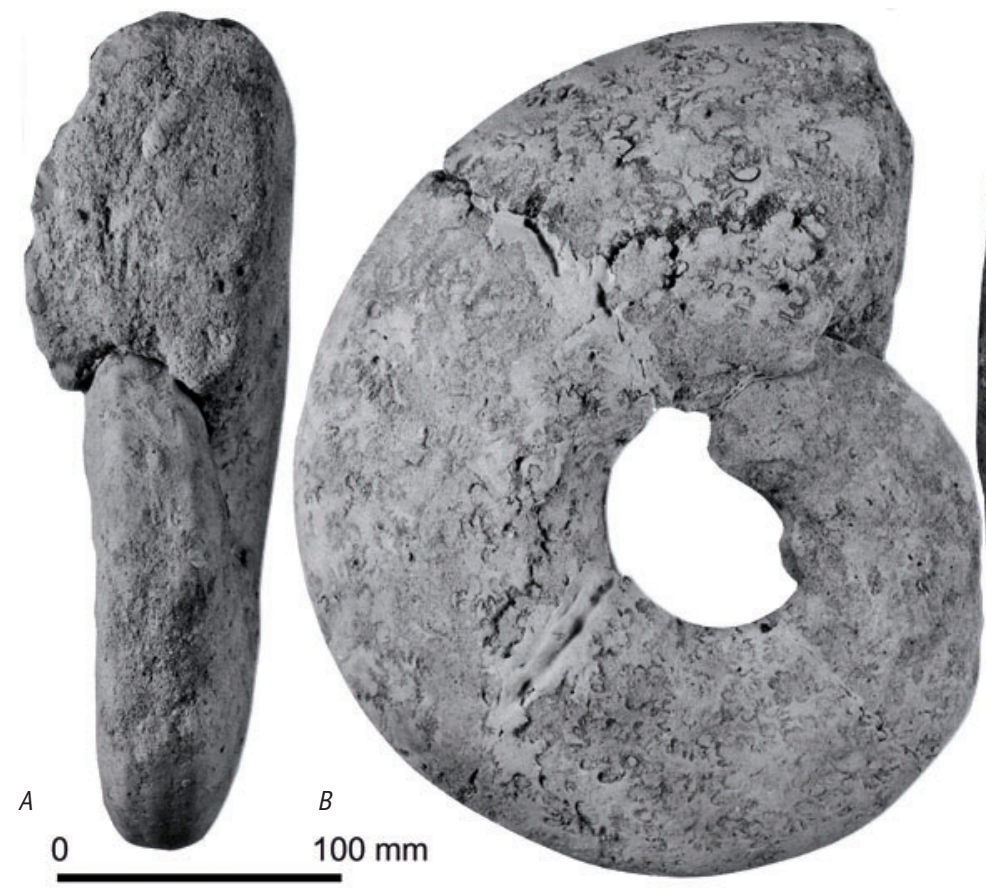

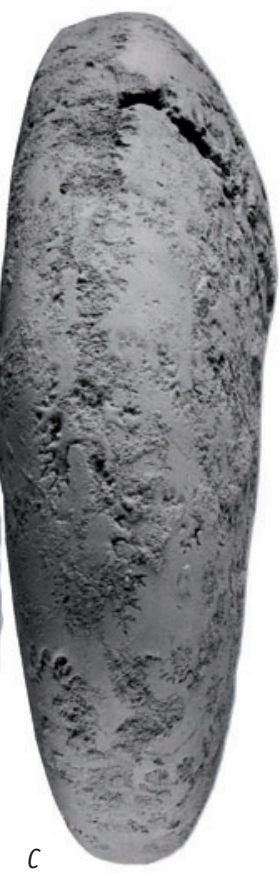

Fig. 12A-C. Acompsoceras renevieri (Sharpe, 1857), IRSCNB 11458, Tourtia de Sassegnies. 


\section{Material}

IRScNB 11458, from the Tourtia de Sassegnies, Sassegnies, northern France (Fig. 7).

\section{Description}

IRScNB 11458 is a large phragmocone, $300 \mathrm{~mm}$ in diameter, of a rather involute form $(\mathrm{U}=80 \mathrm{~mm})$, with a compressed, flatsided whorl section $(\mathrm{Wh}=140 \mathrm{~mm}$; $\mathrm{Wb}=93 \mathrm{~mm})$; the venter is tabulate in the middle growth stage and shows a series of feeble clavi; later the venter is more rounded. Inner whorls are not preserved; the ornament in the middle growth stage is poorly preserved, with only opposite ventral clavi visible. In later growth stages the ornament disappears. Deeply incised elements characterise the suture line, with subphylloid folioles; $\mathrm{E} / \mathrm{L}$ is very wide and, more or less quadrate in outline, while $\mathrm{L}$ is bifid.

\section{Discussion}

Acompsoceras bochumensis and A. essendiensis (see Kaplan et al., 1998, pls 34, 35; pl. 37, figs 4-6) are synonyms of $A$. renevieri. Acompsoceras inconstans (see Kaplan et al., 1998, pl. 36, figs 4, 5; pl. 39) co-occurs with $A$. renevieri, from which it may be distinguished by the presence of a lateral tubercle in early and middle growth.

IRScNB 11458 is a slightly deformed internal mould, in rather coarse-grained, glauconitic calcarenite preservation, pale grey to beige (light brown) in colour, typical of level 'a' at Sassegnies (compare Fig. 7 here; Amédro \& Robaszynski, 2010).

\section{Occurrence}

Lower Cenomanian, especially the Mantelliceras dixoni Zone. There are records from southern England, Westfalen (Germany), Haute-Normandie, Sarthe and Provence in France, Poland, Algeria, Tunisia, Nigeria(?) and Madagascar. The species ranges into the lower Middle Cenomanian Cunningtoniceras inerme Zone in Tunisia.

\section{Acompsoceras inconstans (Schlüter, 1871)}

Figs $13 \mathrm{~A}, \mathrm{~B}, 19 \mathrm{M}, \mathrm{N}$.

1871 Ammonites inconstans Schlüter, p. 7, pl. 3, figs 1-5.

1987 Acompsoceras inconstans (Schlüter, 1871); Wright \& Kennedy, p. 143, text-figs 34c, 41-42, 43a-c, 44; pl. 42, figs 4, 6, 7; pl. 43, fig. 1 (with full synonymy).

1998 Acompsoceras inconstans (Schlüter, 1871); Kaplan et al., p. 138 , pl. 10, figs 8-10; ?pl. 33, figs 1, 2; pl. 36, figs 4, 5; pl. 37, figs 1-3; pl. 39; pl. 42, figs 3, 4 (with additional synonymy).

2010 Acompsoceras renevieri (Sharpe, 1857); Amédro \& Robaszynski, p.35, pl. 4, fig. 2a, b.

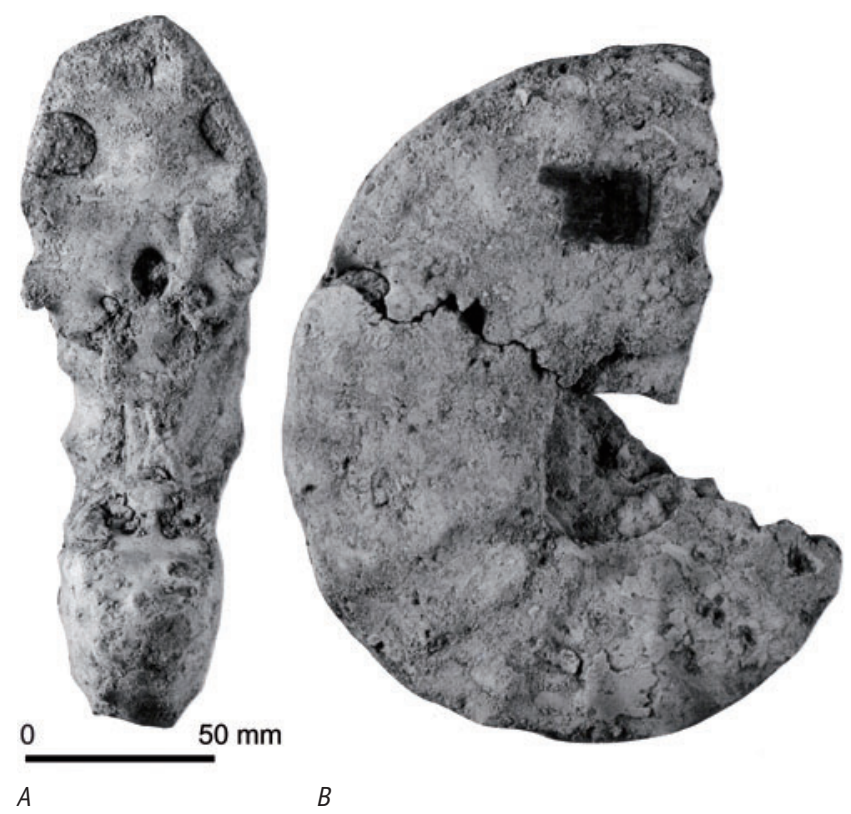

Fig. 13A, B. Acompsoceras inconstans (Schlüter, 1871), IRScNB 11459, Tourtia de Sassegnies.

\section{Types}

Lectotype, by the subsequent designation of Wright \& Kennedy (1987, p. 143), is PIB 30a, the original of Schlüter (1871, pl. 3, figs 1-3), from the Lower Cenomanian Tourtia near Oberhausen Station, Essen, Germany (Kaplan et al., 1998, pl. 39); paralectotype PIB 30b is from the Lower Cenomanian Tourtia of Essen (Kaplan et al., 1998, pl. 36, figs 4, 5).

\section{Material}

IRScNB 11478, from the Meule de Bernissart of Onnaing-lèsValenciennes, northern France; IRScNB 11459, from the Tourtia de Sassegnies, Sassegnies, northern France (Fig. 7).

\section{Description}

IRScNB 11478 (Fig. 19M, N) is a composite mould of a juvenile with a maximum preserved diameter of $84 \mathrm{~mm}$. Coiling appears to have been moderately evolute. The whorls are high, the whorl section compressed. Straight prorsiradiate ribs arise from small umbilical bullae, and strengthen and broaden across the flanks, bearing small lateral bullae, conical inner and clavate outer ventrolateral tubercles. There are occasional shorter intercalated ribs that bear inner and outer ventrolateral tubercles only. There is a marked siphonal ridge, strengthened into incipient clavi opposite the outer ventrolateral clavi.

IRScNB 11459 (Fig. 13A, B) is a huge phragmocone, $183 \mathrm{~mm}$ in diameter $(\mathrm{U}=55 \mathrm{~mm}$; $\mathrm{Wh}=83 \mathrm{~mm} ; \mathrm{Wb}=68 \mathrm{~mm})$. Although badly preserved, it clearly shows very coarse primary ribs with coarse umbilical, lateral, inner and outer ventrolateral tubercles.

\section{Discussion}

The presence of mid-lateral tubercles in early and middle growth characterises this species. 


\section{Occurrence}

Lower Cenomanian, particulary the Mantelliceras dixoni Zone. There are records from southern England, Westfalen (Germany), Haute-Normandie, Sarthe and Provence in France; Algeria, Tunisia, Madagascar, Texas (USA) and northern Mexico.

Genus Acanthoceras Neumayr, 1875

\section{Type species}

Ammonites rhotomagense Brongniart, 1822, pp. 83, 391, pl. 6, fig. 2, by subsequent designation of De Grossouvre (1894, p. 27).

\section{Acanthoceras rhotomagense (Brongniart, 1822)}

Figs $14 \mathrm{~A}, \mathrm{~B}, 15 \mathrm{~A}-\mathrm{C}$.

1822 Ammonites rhotomagensis Defrance; Brongniart, pp. 83, 391, pl. 6, fig. 2.

1987 Acanthoceras rhotomagense (Brongniart, 1822); Wright \& Kennedy, p. 156, text-figs 47-54, 63f-j, 64a, b, 65a-d, k, $66 a, f, g$, j, 67a-g, 68, 69; pl. 42, fig. 8; pl. 44, figs 1-11; pl. 45, figs 1-5; pl. 46, figs 1-4, 6; pl. 47, figs 1 , 2; pl. 48, figs 1, 2; pl. 49, figs 1, 5, 6; (with full synonymy).

1998 Acanthoceras rhotomagense (Brongniart, 1822); Kaplan et al., p. 140, pl. 41, fig. 3; pl. 42, figs 1, 2; pls 43-46; pl. 47, figs 1-3; pl. 54, figs 1, 3, 4 (with additional synonymy).

\section{Type}

The lectotype, by subsequent designation of H. Douvillé (1912), is the original of Brongniart (1822, pl. 6, fig. 2), an unregistered specimen in the Sorbonne Collections, now in the collections of the Muséum national d'Histoire naturelle, Paris. It is from Rouen (Seine-Maritime, France; see Wright \& Kennedy, 1987, text-fig. 63f-h).

\section{Material}

IRScNB 11460 and 11461, both from Tournai, Hainaut.

\section{Dimensions}

\begin{tabular}{|c|c|c|c|c|c|}
\hline & D & $\mathrm{Wb}$ & Wh & Wb:Wh & U \\
\hline \multirow[t]{2}{*}{ RScNB 11460} & $77.0(100)$ & $-(-)$ & $33.0(42.9)$ & & 21.5 \\
\hline & 53.5 & $30.7(57.4)$ & $22.8(42.6)$ & 1.35 & $16.1(29.1)$ \\
\hline ScNB 11461 & $94.5(100)$ & $54.0(57.1)$ & $40.5(42.9)$ & 1.26 & 31.8 (33.7) \\
\hline
\end{tabular}

\section{Description}

IRScNB 11460 (Fig. 14A, B) appears to be lightly phosphatised, with a conglomeratic infill. Coiling is evolute, the umbilicus comprising 28 per cent of the diameter, of moderate depth, with a feebly convex wall and more narrowly rounded umbilical shoulder. The whorl section is depressed, trapezoidal in intercostal section and polygonal in costal section, with a whorl breadth to height ratio of 1.35 . There are 23 ribs per whorl at a diameter of $53.5 \mathrm{~mm}$. Almost all of the ribs on the outer whorl are primaries; most of them are single and arise at feeble umbilical bullae; a few lack bullae. They are feebly flexed, broaden progressively across the flanks, projecting forwards, and are feebly concave on the outermost flank and ventrolateral shoulder. All ribs bear equal conical inner and clavate outer ventrolateral tubercles, the latter linked over the venter by a weak to effaced transverse rib, with a weak siphonal clavus.

IRSCNB 11461 (Fig. 15A-C) is a more coarsely ornamented individual, with 24 ribs per whorl at a diameter of $94.5 \mathrm{~mm}$. All of the ribs on the outer whorl are primaries, with stronger ventrolateral and ventral tuberculation. The specimen appears to be lightly phosphatised, and retains traces of phosphatised shell.
Fig. 14A, B. Acanthoceras rhotomagense (Brongniart, 1822), IRSCNB 11460, Tourtia de Tournai, Tournai (Hainaut). Figures are $\times 1$.
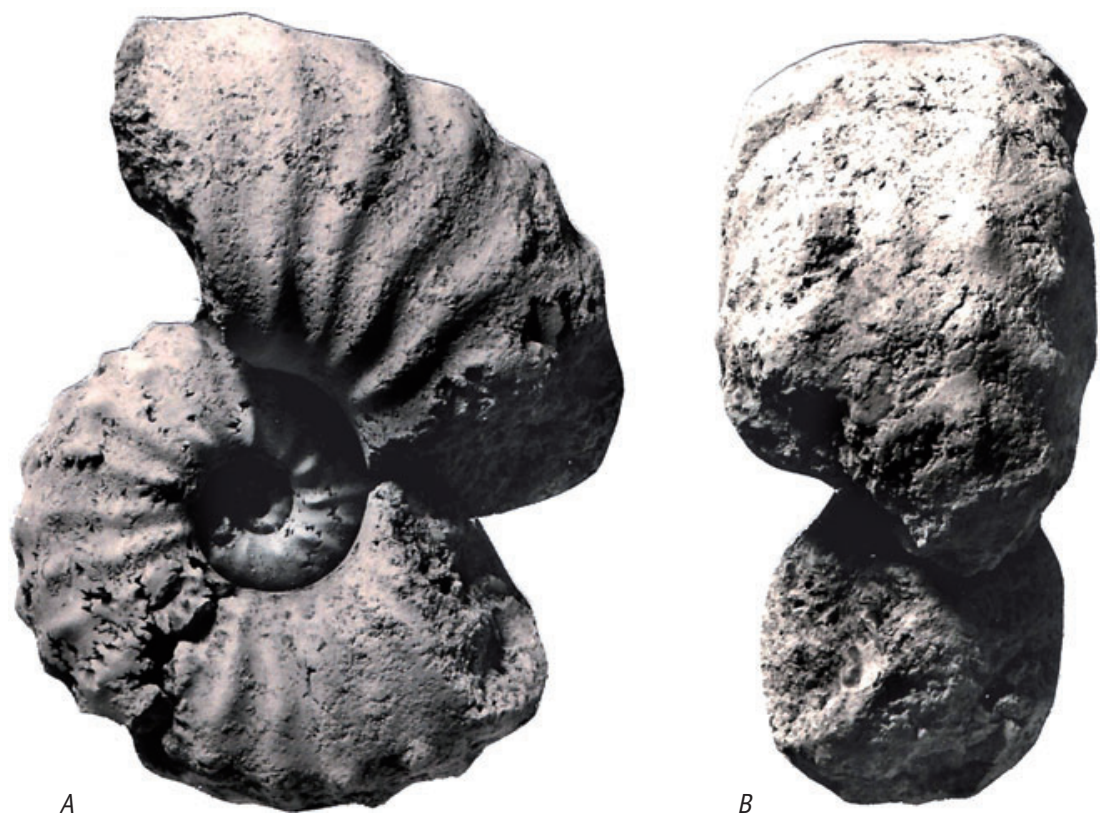

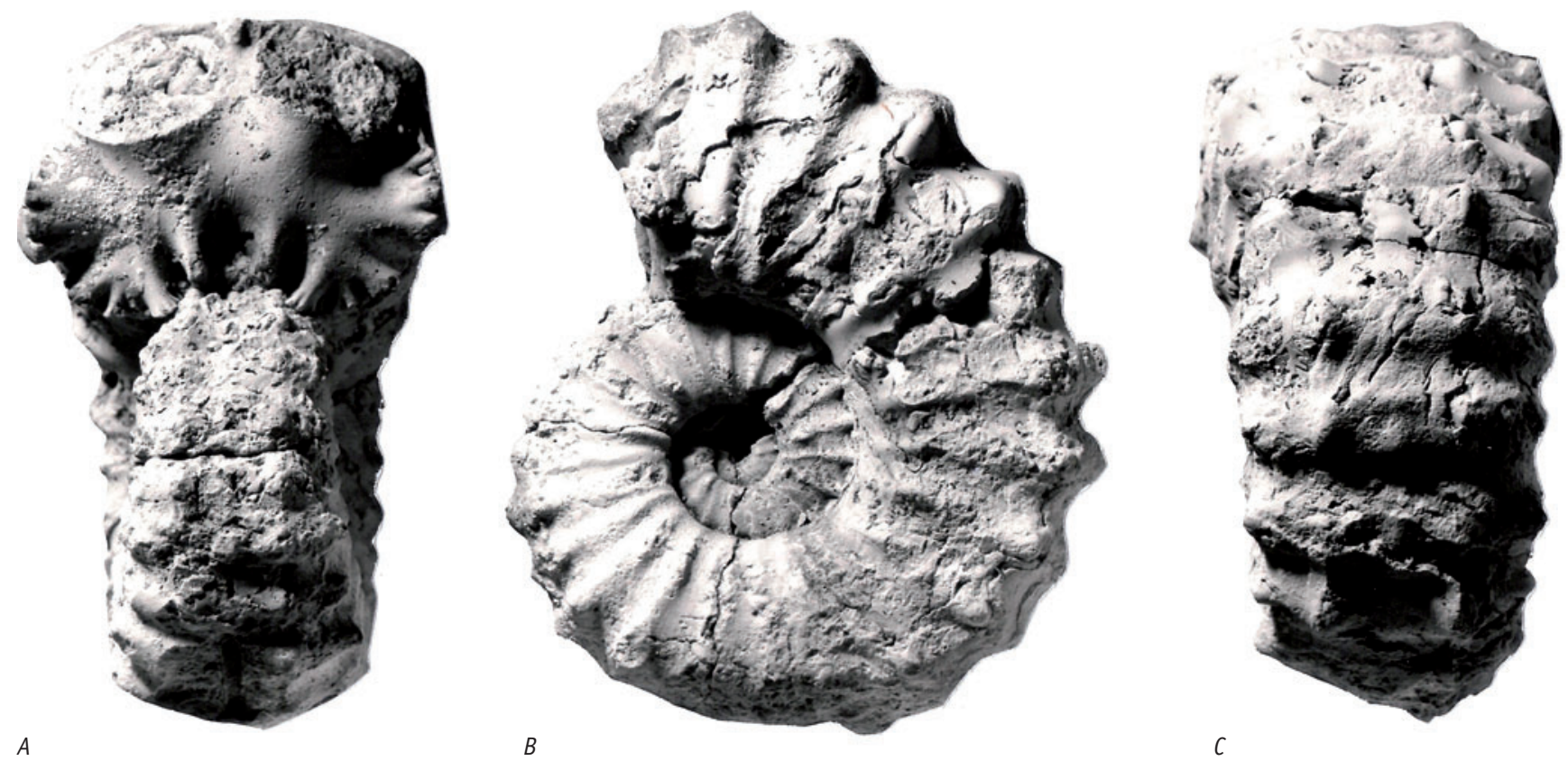

Fig. 15A-C. Acanthoceras rhotomagense (Brongniart, 1822), IRSCNB 11461, Tourtia de Tournai, Tournai (Hainaut). Figures are $\times 0.8$.

\section{Discussion}

Kennedy \& Hancock (1970) and Juignet \& Kennedy (1976) provided extensive descriptions and numerous illustrations of topotypes and other material from Haute-Normandie, and Thomel (1972), under a variety of names, specimens from Provence. Wright \& Kennedy (1987) placed a host of taxa in synonymy of a single variable species, described the variation, and illustrated a wealth of English material. IRScNB 11460 corresponds to a morphotype intermediate between subflexuosum of Spath (1923, p. 144, based on Ammonites rhotomagensis Defrance of J. de C. Sowerby, 1826, pl. 515, fig. 1, reillustrated by Kennedy \& Hancock, 1970, pl. 90, fig. 1) and sussexiense of Mantell, 1822 (p. 114, pl. 20, fig. 2; reillustrated by Wright \& Kennedy, 1987, text-figs 51, 52). IRScNB 11461 is a sussexiense morphotype.

Acanthoceras rhotomagense is succeeded by A. jukesbrownei (Spath, 1926b) (p. 82; see revision in Wright \& Kennedy, 1987, p. 191, text-figs 55-62, 64c, 65e, f, h-j, l, m, 67h-q; pl. 49, figs 2-4; pl. 50, figs 1-5; pl. 51, figs 1-7), adults of which have few coarse, distant ribs with strong umbilical bullae, inner ventrolateral tubercles that decline to give a characteristic trapezoidal rather than polygonal whorl section. Many such individuals have alternately long and short ribs that persist to maturity, a feature that readily distinguishes them from $A$. rhotomagense, but some specimens have the distinctive whorl section of $A$. jukesbrownei but lack persistent short ribs, so that the latter character cannot, of its own, be used to separate the two. Differences from other species were discussed by Wright \& Kennedy $(1987$, pp. 155, 187).

\section{Occurrence}

Middle Cenomanian, Acanthoceras rhotomagense Zone. The species occurs in western Europe from Northern Ireland through England, Westfalen (Germany), France (Boulonnais to Provence),
Denmark (Bornholm), northern Spain, east to Turkmenistan and northern Iran, Romania, North Africa, the Middle East, southern India, and possibly Peru and Bathurst Island, northern Australia.

\section{Acanthoceras $s p$.}

Fig. 16Q-T.

\section{Material}

IRSCNB 11464 and IRSCNB 11465, labelled 'assize de Saint Aybert, Tourtia de Mons, Boussières-sur-Sambre, près Hautmont', but more probably from Bed ' $\mathrm{e}$ ' of Barrois (1878), which is the basal phosphatic nodule bed of the Tourtia de Mons in northern France (see Fig. 7).

\section{Description}

IRScNB 11465 (Fig. 16S, T) is a brown phosphatic internal mould of two chambers with a maximum preserved whorl breadth of $18 \mathrm{~mm}$. The presence of strong subspinose inner ventrolateral tubercles and outer ventrolateral clavi and weaker siphonal clavi show this to be a juvnile Acanthoceras. IRScNB 11464 (Fig. $16 Q, R)$ is a larger fragment of parts of three camerae in similar preservation, with traces of grey glauconitic chalky matrix. The maximum preserved whorl height is $28 \mathrm{~mm}$. The whorl section appears to have been slightly depressed trapezoidal in intercostal section. Weak umbilical bullae give rise to weak prorsiradiate ribs that broaden and strengthen across the flanks and bear weak inner, and stronger, clavate outer ventrolateral tubercles. A single intercalated rib separates successive primaries, and lacks an inner ventrolateral tubercle. The outer ventrolateral tubercles are linked across the venter by a low, broad, effaced rib. There are no clearly differentiated siphonal tubercles. 


\section{Discussion}

These fragments belong to either $A$. rhotomagense or more probably, in view of their provenance, to A. jukesbrownei (Spath, 1926b) (see Wright \& Kennedy, 1987, p. 191, text-figs 55-62, 64c, 65e, f, h-j, l, 66e, 67h-q; pl. 49, figs 2-4; pl. 50, figs 1-5; pl. 51, figs 1-7), but lack the clear differentiating features of the two species, as will be seen from a comparison of the larger of the two present specimens with the feebly ornamented $A$. rhotomagense illustrated by Wright \& Kennedy (1987, pl. 44, fig. 11), and the feebly ornamented $A$. jukesbrownei figured as their pl. 51, fig. 5 .

\section{Occurrence}

As for material; the specimens indicate either the Middle Cenomanian Acanthoceras rhotomagense or, more probably, the overlying Acanthoceras jukesbrownei Zone (see discussion in Amédro \& Robaszynski, 2010, pp. 18, 20).

\section{Subfamily Mammitinae Hyatt, 1900}

Genus Mammites Laube \& Bruder, 1887

\section{Type species}

Ammonites nodosoides Schlüter, 1871, p. 19, pl. 8, figs 1-4, by monotypy (see Wright \& Kennedy, 1981, p. 75).

\section{Mammites nodosoides (Schlüter, 1871)}

Fig. 16A-P.

1871 Ammonites nodosoides Schlüter, p. 19, pl. 8, figs 1-4.

1981 Mammites nodosoides (Schlüter, 1871); Wright \& Kennedy, p. 75, text-figs 19b, 23, 24; pl. 17, fig. 3; pl. 19, fig. 3; pl. 20, fig. 4; pl. 22, fig. 4; pl. 23, figs 1-3; pl. 24, figs 2,3 (with synonymy).

2007 Mammites nodosoides (Schlüter, 1871); Barroso-Barcenilla, p. 148, pl. 11, figs a-d (with additional synonymy).

2008 Mammites nodosoides (Schlüter, 1871); Kennedy et al., p. 154, pl. 1, figs 1-5; pl. 2, fig. 8 (with additional synonymy). 2009 Mammites nodosoides (Schlüter, 1871); Lehmann \& Herbig, p. 71, pl. 1, figs n, 0 .

\section{Types}

The lectotype, by subsequent designation of Wright \& Kennedy (1981, p. 76), is no. C555 in the Museum für Naturkunde (Humboldt Universität Berlin), one of the syntypes on which Schlüter based his species (1871, p. 21, footnote 1), reillustrated Wright \& Kennedy (1981, text-fig. 23). It is from the Lower Turonian of Měcholup, Czech Republic. There are two paralectotypes, both from the Lower Turonian of Westfalen (Germany).

\section{Material}

IRScNB 11462, from the Marne Grise of Autreppe, Hainaut, and IRScNB 11463, from above the Tourtia de Tournai of Tournai, Hainaut.

\section{Description}

IRScNB 11462 is a worn, brown-black phosphatic internal mould of a phragmocone with a maximum preserved diameter of $27 \mathrm{~mm}$. Coiling is moderately involute, the umbilicus shallow, with a feebly convex umbilical wall and more narrowly rounded umbilical shoulder. The whorl section is compressed, roundedtrapezoidal in intercostal section and polygonal in costal section, with the greatest breadth at the umbilical bullae. There are an estimated 12 progressively strengthening subspinose umbilical bullae on the outer whorl. These give rise to strong straight prorsiradiate ribs that strengthen and broaden across the flanks and link to conical inner ventrolateral tubercles, linked in turn by a broad prorsiradiate rib to strong outer ventrolateral clavi. There are occasional non-bullate primary ribs and shorter intercalated ribs, all with inner and outer ventrolateral tubercles. The venter is narrow. The poorly preserved penultimate whorl (Fig. 16J) is closely and finely ribbed. The sutures are only partially preserved; E/A is broad and moderately incised, A is narrow, and $A / U_{2}$ small and moderately incised.

IRScNB 11463 (Fig. 16E-H, M-P) is a black phosphatic internal mould of a $180^{\circ}$ sector of phragmocone with a maximum preserved diameter of $30 \mathrm{~mm}$, with traces of grey chalky sediment with scattered small glauconite grains. Coiling appears to have been involute, with a small umbilicus. The umbilicus is shallow, with a low convex wall and more narrowly rounded umbilical shoulder. The intercostal whorl section is rectangular, with broadly rounded ventrolateral shoulders and a very feebly convex venter. The costal section is polygonal with the greatest breadth at the umbilical bullae, the rib profile concave between the umbilical bullae and the inner ventrolateral, inner and outer ventrolateral, and outer ventrolateral tubercles. Five small umbilical bullae are preserved on the fragment. They give rise to single low prorsiradiate ribs that broaden and strengthen across the flank, and a second rib may be tenuously linked to a bulla. There are non-bullate primaries and shorter intercalated ribs to give a total of nine ribs on the ventrolateral shoulder of the fragment, each bearing a conical inner ventrolateral tubercle. These tubercles are linked to somewhat larger outer ventrolateral clavi by a low, broad prorsiradiate rib. There is a very feeble siphonal ridge. The suture is moderately incised, with a broad asymmetrically bifid $\mathrm{E} / \mathrm{A}$, that declines from $\mathrm{E}$ to $\mathrm{A}$, a narrow $\mathrm{A}$, and simplifying $\mathrm{A} / \mathrm{U}_{2}$ and $\mathrm{U}_{2} / \mathrm{U}_{3}$.

\section{Discussion}

Although poorly preserved, these specimens are clearly $M$. nodosoides, IRScNB 11463 comparing well with a specimen from New Mexico illustrated by Cobban \& Hook (1983, pl. 4, figs 4-6), 

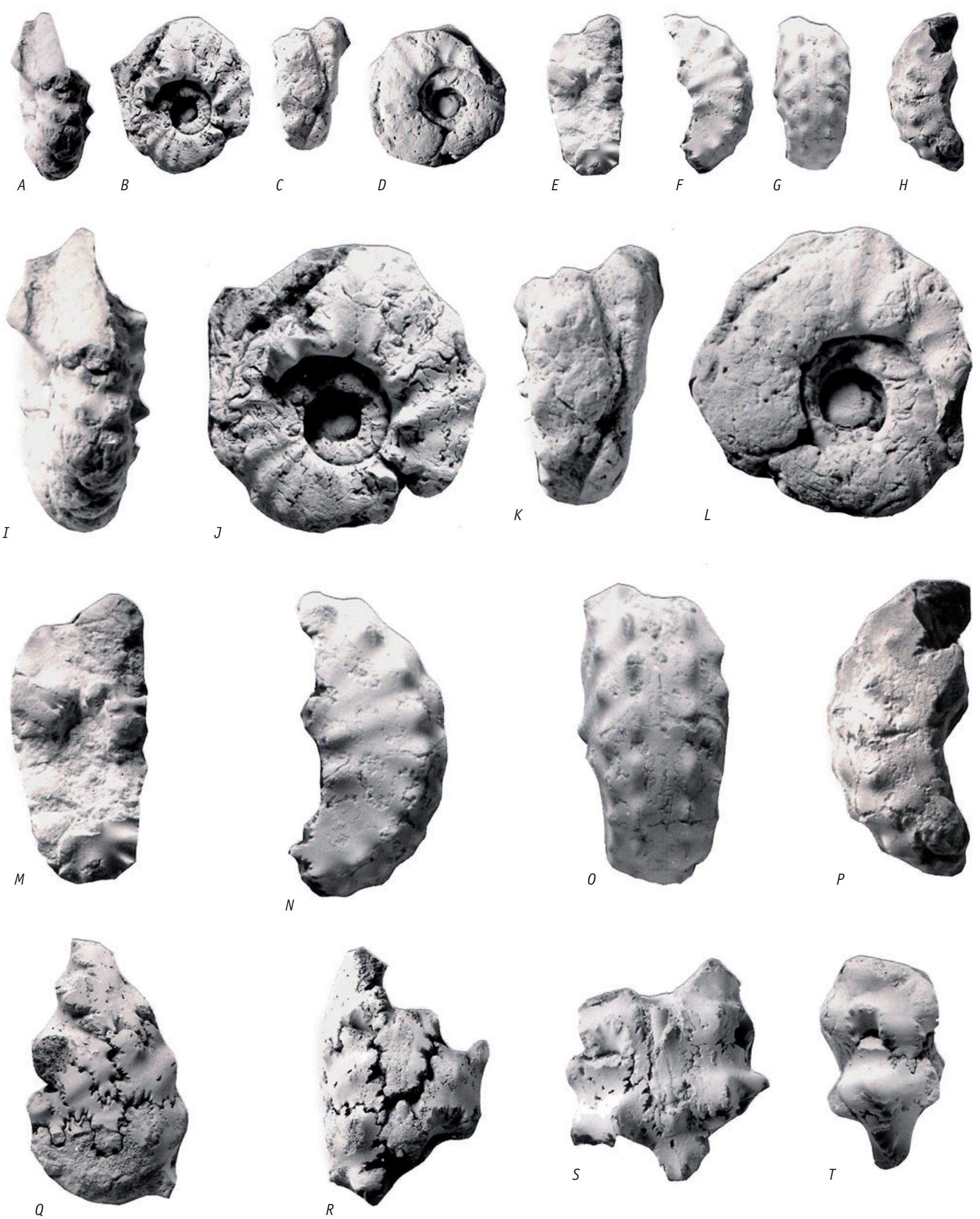

Fig. 16A-P. Mammites nodosoides (Schlüter, 1871); A-D, I-L are IRSCNB 11462, Marne Grise, Autreppe (Hainaut); E-H, M-P are IRSCNB 11463, Tourtia de Tournai, Tournai (Hainaut); Q-T. Acanthoceras sp., Q-R are IRSCNB 11464; S, T are IRScNB 11465, Tourtia de Mons, Boussières-sur-Sambre, near Hautmont (Nord, France). Figures A-H, Q-T are $\times 1 ; I-P$ are $\times 2$. 
which, although larger and more inflated, shows the same relatively finely ribbed nucleus at the same diameter as the present specimen. The other specimen, IRScNB 11462, matches juveniles of this species figured by Cobban \& Hook (1983, pl. 4, figs 4-9). The matrix remains in the latter clearly shows that it cannot have originated from the Tourtia de Tournai, but rather must be from a higher level, within the 'Dièves'.

\section{Occurrence}

Upper lower Turonian Mammites nodosoides Zone and correlatives, with records from Germany, France, southern Belgium, England, Spain, the Czech Republic, Romania, Turkmenistan, Lebanon, Israel, Egypt, Tunisia, Algeria, Morocco, Nigeria, Madagascar, Peru, Brazil, Colombia, Mexico and the United States Western Interior.

Family Vascoceratidae H. Douvillé, 1912

Genus Fagesia Pervinquière, 1907

\section{Type species}

Olcostephanus superstes Kossmat, 1897, p. 26 (133), pl. 6 (17), fig. 1 only, by original designation (Pervinquière, 1907, p. 322).

\section{Fagesia $s p$.}

Fig. 9S, T.

\section{Material}

IRScNB 11442, from the 'Marne Grise' (or 'Dièves') of Autreppe, Hainaut.

\section{Description}

The specimen is a worn black phosphatic internal mould of a single chamber. The coiling can be reconstructed as very evolute, with a large, deep, crater-like umbilicus, the umbilical wall flattened and outward-inclined, the umbilical shoulder narrowly rounded. The whorl section is very depressed, with a maximum preserved whorl height of $21.2 \mathrm{~mm}$ and a whorl breadth to height ratio of 1.92 . There are no flanks. The venter is very wide and broadly convex. A coarse bulla perches on the umbilical shoulder of the single camera, and gives rise to a single broad, coarse rib that crosses the venter in a broad convexity.

\section{Discussion}

Although only a single chamber, this fragment is immediately recognisable as a ribbed Fagesia with umbilical bullae. There are close similarities to juvenile Fagesia catinus (Mantell, 1822) of comparable size, for example well-preserved individuals illustrated by Cobban et al. (1989, pl. 92, figs L-KK).

\section{Occurrence}

Fagesia ranges from the upper Upper Cenomanian to the Middle Turonian.
Family Collignoniceratidae Wright \& Wright, 1951

Subfamily Collignoniceratinae Wright \& Wright, 1951 Genus Collignoniceras Breistroffer, 1947

\section{Type species}

Ammonites woollgari Mantell, 1822, p.197, pl. 21, fig. 16; pl. 22, fig. 7, by the original designation of Meek (1876, p. 453), as type species of Prionotropis Meek, 1876 non Fieber, 1853, for which Breistroffer (1947, unpaginated) proposed Collignoniceras as nomen novum.

\section{Collignoniceras woollgari regulare (Haas, 1946)}

Fig. 17A, B.

2001 Collignoniceras woollgari regulare (Haas, 1946); Kennedy et al., p. 45, figs 17-33, 49L (with full synonymy).

\section{Type}

The holotype, by original designation, is no. 1470 in the collections of the South Dakota School of Mines, Rapid City, the original of Haas (1946, text-figs 80, 81; pl. 16, figs 14, 16), from an unknown horizon and locality in the Black Hills area of South Dakota, USA.

\section{Material}

IRScNB 11466 and IRScNB 11483, from the 'Dièves' at Anderlues, Hainaut.

\section{Description}

IRScNB 11466 and IRScNB 11483 are distorted composite moulds with a thin surface coating of black pyrite, preserved in grey marl with scattered glauconite grains. IRScNB 11466 (Fig. 17A, B) is a $90 \mathrm{~mm}$ long fragment, crushed dorso-ventrally. Three strong bullae perch on the umbilical shoulder and give rise to single strong, narrow ribs that link to coarse inner ventrolateral clavi. There is a single shorter intercalated rib on the fragment, with an inner ventrolateral clavus. The inner ventrolateral clavi are linked to weaker outer ventrolateral clavi by a low broad swelling, sometimes incipiently differentiated into a pair of looped ribs. The venter is badly damaged, but one rib bears a weak siphonal clavus at mid-venter. IRScNB 11483 (not illustrated), a $100 \mathrm{~mm}$ long fragment, has been similarly deformed. It bears three narrow strong ribs that bear massive inner ventrolateral horns and weaker outer ventrolateral clavi. Any mid-ventral ornament has been obliterated by the crushing.

\section{Discussion}

Poor as this material is, it clearly belongs to $C$. woollgari. Two subspecies are recognised, as revised by Kennedy et al. (2001). Collignoniceras $w$. woollgari and C. w. regulare differ in that the nominate subspecies has more siphonal than ventrolateral tubercles on middle and late phragmocone whorls, and looped 


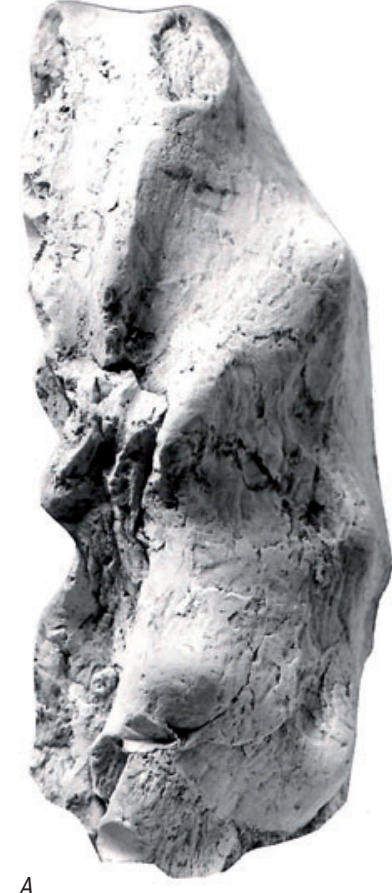

A

ribs connecting opposite ventrolateral horns. These features also generally separate adult body chambers.

\section{Occurrence}

Upper part of the Middle Turonian Collignoniceras woollgari Zone, with records from southern England, southern Belgium, France, the US Western Interior, California, Oregon, and Chihuahua, northern Mexico.

\section{Suborder Ancyloceratina Wiedmann, 1966 \\ Superfamily Turrilitoidea Gill, 1871 \\ Family Hamitidae Gill, 1871 \\ Genus Hamites Parkinson, 1811}

\section{Type species}

Hamites alternatus J. Sowerby, 1814, p. 137, pl. 61, figs 4, 5, by subsequent designation of Diener (1925, p. 65).

Hamites simplex d'Orbigny, 1842

Fig. 19H, I.

1842 Hamites simplex d'0rbigny, p. 550, pl. 134, figs 12-14.

1995 Hamites simplex d'Orbigny; Wright \& Kennedy, p. 296, text-figs 128c, 131e-h, m, o, 133d-l; pl. 87, figs 6, 9, 11-13, 15-18; pl. 88, figs 11-13 (with full synonymy).

2006 Hamites simplex d'Orbigny; Kennedy \& Juignet in Gauthier, p. 162 , pl. 51, figs 4-11.

\section{Types}

Sornay (1955, fig. 1) designated a lectotype from amongst $\mathrm{d}^{\prime}$ Orbigny's eight surviving syntypes. The specimens were
Fig. 17A, B. Collignoniceras woollgari regulare (Haas, 1946), IRSCNB 11466, 'Dièves', Anderlues (Hainaut). Figures are $\times 1$. reillustrated by Wright \& Kennedy (1995, text-fig. 133d-l), and Kennedy \& Juignet in Gauthier (2006, pl. 51, figs 4-11), and are from the Middle Cenomanian of Rouen (Seine-Maritime, France).

\section{Material}

IRScNB 11476, from the Tourtia de Tournai of Tournai, Hainaut.

\section{Description}

The specimen is a $22.5 \mathrm{~mm}$ long limonitic internal mould retaining traces of iridescent limonitised shell. The fragment is straight, with a maximum preserved whorl height of $8 \mathrm{~mm}$. The whorl section is circular, the rib index 5 . The ribs are weakened and transverse on the dorsum, strengthen across the dorsolateral margin, and are narrow, sharp, straight and feebly prorsiradiate across the flanks, and transverse on the venter. At the adapertural end, a markedly strengthened rib is succeeded by a broad and deep constriction, in turn succeeded by a single, weaker rib, showing the specimen to be from the adapertural end of the body chamber of an adult microconch.

\section{Discussion}

Hamites simplex differs from $H$. duplicatus Pictet \& Campiche, 1861 (p. 98; see revision in Wright \& Kennedy, 1995, p. 298, pl. 87, figs $1,2,7,8,10$; pl. 88, figs 2, 4) in that the latter has a much higher rib index (7-9), the ribs being fine and dense, with a tendency to split into two lirae on internal moulds.

\section{Occurrence}

The species ranges from the Lower Cenomanian Mantelliceras mantelli Zone, where it is rare, through the Middle Cenomanian Acanthoceras rhotomagense and Acanthoceras jukesbrownei zones, where it is commoner, into the Upper Cenomanian 
Calycoceras guerangeri Zone, where it is again infrequent. The geographic range extends from southern England to Hainaut, southern Belgium, France (Boulonnais south to the Mediterranean coast at Cassis, Bouches-du-Rhône), Poland, Iran, Daghestan, Algeria, Tunisia, Madagascar, Bathurst Island (northern Australia) and the US Western Interior.

Family Turrilitidae Gill, 1871

Genus Turrilites Lamarck, 1801

\section{Type species}

Turrilites costatus Lamarck, 1801, p. 102, by original designation.

Turrilites acutus Passy, 1832

Fig. 20.

1832 Turrilites acutus Passy, p. 9, pl. 16, figs 3, 4.

1996 Turrilites acutus Passy, 1832; Wright \& Kennedy, p. 358, text-figs 138m, 141a, 146n, 0; pl. 103, fig. 3; pl. 104, figs 5, 7, 11; pl. 105, fig. 21; pl. 108, figs 1-4, 8, 11, 12 (with full synonymy).

1998 Turrilites acutus Passy, 1832; Kaplan et al., p. 216, pl. 60, fig. 4; pl. 63, figs 1-5; pl. 64, fig. 2.

\section{Type}

The lectotype, by subsequent designation of Juignet \& Kennedy (1976, p. 65), is the original of Passy (1832, pl. 16, fig. 3), an unregistered specimen from the Middle Cenomanian of Rouen (Seine-Maritime, France) in the Sorbonne Collections, now housed at the Muséum national d'Histoire naturelle (Paris).

\section{Material}

NHMW 1857 XX 6, from Tournai, Hainaut.

\section{Description}

The specimen consists of three whorls, in typical limonitic preservation, with limonitised shell retained. The total height of the fragment is $30 \mathrm{~mm}$. There are 18 ribs per whorl. They arise at the top of the outer whorl face and strengthen into sharp tubercles at a marked angulation in the whorl profile. A feeble prorsiradiate rib links to a second row of conical, feebly spirally elongated tubercles low on the outer whorl face. A third row of smaller tubercles is partially concealed in the interwhorl suture.

\section{Discussion}

Turrilites acutus most closely resembles $T$. costatus, from which it probably arose. The two differ in that the former has a lower whorl, ornamented by three rows of tubercles linked by weak or no ribs; in $T$. costatus, a strong rib covers the upper half of the outer whorl face, terminating in a variably developed tubercle or not, with two rows of tubercles below.

\section{Occurrence}

Middle Cenomanian, upper half of the Acanthoceras rhotomagense Zone, to lower Upper Cenomanian Calycoceras guerangeri Zone. The species occurs widely across Europe and Central Asia to Kazakhstan and Turkmenistan, in North Africa, the Middle East, Nigeria, Angola, Zululand (South Africa), Mozambique, Madagascar, Tibet, Texas, the US Western Interior and California.

Genus Mesoturrilites Breistroffer, 1953

\section{Type species}

Turrilites aumalensis Coquand, 1862, p. 323, pl. 35, fig. 5, by original designation (Breistroffer, 1953, p. 1351).

Mesoturrilites corrugatus Wright \& Kennedy, 1996

Fig. 19C.

?1876 Turrilites puzosianus d'Orbigny; Schlüter, p. 128, pl. 38, figs 13, 14.

1974 Ostlingoceras (Ostlingoceras) puzosianum (d'Orbigny); Marcinowski, p. 170, pl. 32, fig. 6.

1996 Mesoturrilites corrugatus Wright \& Kennedy, p. 348, pl. 98, figs 4, 17.

1998 Mesoturrilites corrugatus Wright \& Kennedy; Kaplan et al., p. 212, pl. 65, figs 4,5 .

\section{Types}

The holotype is BGS.GSM Zb692, the original of Wright \& Kennedy (1996, pl. 98, fig. 4) from the Lower Cenomanian Hypoturrilites carcitanense Subzone fauna of the Mantelliceras mantelli Zone near Norton Ferris (Wiltshire, England). Paratype 0UM K38108 is the original of Wright \& Kennedy (1996, pl. 98, fig. 17) from the Lower Cenomanian Mantelliceras dixoni Zone fauna of the Lower Chalk of Southerham, near Lewes (Sussex, England).

\section{Material}

IRScNB 11474, from the Tourtia de Tournai of Tournai.

\section{Description}

The specimen is a limonitised fragment of 1.25 whorls, retaining limonitised shell. The adapical end is a septal face. The maximum preserved whorl height is $6.1 \mathrm{~mm}$. The apical angle is low. The upper part of the outer, exposed whorl face is convex, the remainder flattened. There are 19 ribs per whorl. They are coarse, rounded, straight and normal to the upper interwhorl suture, at which they arise, and extend across the upper half of the outer whorl face. They efface, and a broad near-smooth zone separates them from a similar number of rounded, spirally elongated tubercles. A narrow groove separates these tubercles from a spiral ridge, strengthened into weak spirally elongated tubercles that alternate in position with those in the row 
above, and are concealed beneath the interwhorl suture. The base of the whorl bears delicate concave ribs that arise from these tubercles, together with growth lines and striae, all of which weaken towards the umbilicus.

\section{Discussion}

The species differs from congeners in being ribbed, rather than tuberculate. It is superficially similar to juvenile Turrilites scheuchzerianus Bosc, 1801, of similar size (see e.g., Gale et al., 1999, pl. 1, figs 23-25), from which it is distinguished by the presence of two rows of tubercles in addition to the ribs, rather than being ornamented by ribs that are weakened and effaced at mid-flank in juveniles.

\section{Occurrence}

Apart from the present record, the species in known from Lower Cenomanian (Mantelliceras mantelli and Mantelliceras dixoni zones) of southern England, the undifferentiated Cenomanian of Westfalen (Germany) and the condensed ?Upper Albian to Cenomanian of Poland.

Family Baculitidae Gill, 1871

Genus Sciponoceras Hyatt, 1894

\section{Type species}

Hamites baculoides Mantell, 1822, p. 123, pl. 23, figs 6, 7, by original designation (Hyatt, 1894, p. 578).

\section{Sciponoceras baculoides (Mantell, 1822)}

Fig. 18A-R.

1822 Hamites baculoides Mantell, p. 123, pl. 23, figs 6, 7.

1995 Sciponoceras baculoides (Mantell, 1822); Wright \& Kennedy, p. 317, text-figs 129h, 132r, 133a-c, m-ff; pl. 95, figs 1-3, 5-10; pl. 96, figs 1-7; pl. 97, figs 1-5; pl. 98, figs 29-32 (with full synonymy).

1998 Sciponoceras baculoides (Mantell, 1822); Kaplan et al., p. 188, pl. 59, figs 6-11.

\section{Types}

The lectotype, by the subsequent designation of Kennedy (1971, p. 9), is the larger specimen of two on BMNH 8612 (Wright \& Kennedy, 1995, pl. 95, fig. 9). Paralectotypes are the smaller specimen on BMNH 8612 and BMNH 3657a (Wright \& Kennedy, 1995, pl. 95, fig. 7). All are from the Lower Chalk, presumed Middle Cenomanian, of Hamsey (Sussex, England).

\section{Material}

IRScNB 11467-11470 and IRScNB 11481, all from the Tourtia de Tournai of Tournai, Hainaut; IRScNB 11471, from the Tourtia de Tournai of Carrière Delwart, Pont-à-Rieu, Chercq, near Tournai, Hainaut; IRScNB 11472, from the Tourtia de Tournai of Carrière du Cornet, Chercq, near Tournai, Hainaut; BMNH 30819a, b from the Tourtia de Montignies-sur-Roc.

\section{Description}

Specimens occur in two different preservation styles. IRScNB 11467, 11468, 11470, 11481 and BMNH 30819a, b are limonitised, and retain traces of limonitised shell. IRScNB 11469 is preserved in pale-buff micritic and possibly phosphatised limestone with phosphatised shell and only traces of limonite staining. In contrast, the Cherq specimens are preserved as internal moulds in off-white, fine-grained limestone with abundant small glauconite grains. Phragmocones such as IRScNB 11470 (Fig. 18P-R) have whorl heights of as little as $5.7 \mathrm{~mm}$, with a compressed ovoid whorl section, the venter slightly more rounded than the dorsum. The whorls expand very slowly. Internal moulds of phragmocones are smooth but for periodic prominent constrictions, one in a distance equal to twice the whorl height. The constrictions are transverse and weak on the dorsum, strengthening markedly on the dorsolateral margin, producing a distinctive dorsal appearance (Fig. 18C, D, P). They are strongly prorsiradiate on the flanks, and cross the venter in a broad convexity. Well-preserved body chambers have whorl heights of up to $11.5 \mathrm{~mm}$ (Fig. 18G-L), and develop distinctive prorsiradiate ribs on the outer flank that cross the venter in a broad convexity, where they have a scale-like appearance, the adapical slope of the rib gently inclined, the adapertural slope steep.

IRScNB 11481 are much larger fragments of body chamber, with whorl heights of up to $16 \mathrm{~mm}$, while IRScNB 11470 shows the suture, with moderately incised, strongly bifid E/A, A, A/U, $\mathrm{U}$, and U/I.

\section{Discussion}

Wright \& Kennedy $(1995$, p. 318$)$ are referred to for an extensive description and discussion of this species. Sciponoceras baculoides differs from Sci. roto Cieśliński, 1959 (pp. 39, 75, 89, text-fig. 14(2); pl. 4, fig. 10) in that the latter has a circular rather than oval whorl section, and more widely spaced, feeble constrictions separated by a distance of up to three whorl heights (see below).

\section{Occurrence}

This is the second commonest ammonite in the fauna of the Tourtia de Tournai. In southern England, Sci. baculoides occurs in flood abundance at the top of the Middle Cenomanian Turrilites costatus Subzone of the Acanthoceras rhotomagense Zone in the Lower Chalk, and in the phosphatised faunas of the Chalk Basement bed of comparable age in Dorset. It ranges to the lower Upper Cenomanian Calycoceras guerangeri Zone. The species is also known from Westfalen (Germany), France, Switzerland, Poland, Romania, North Africa, Madagascar, Zululand (South Africa), South India, Japan (as a subspecies) and California. 

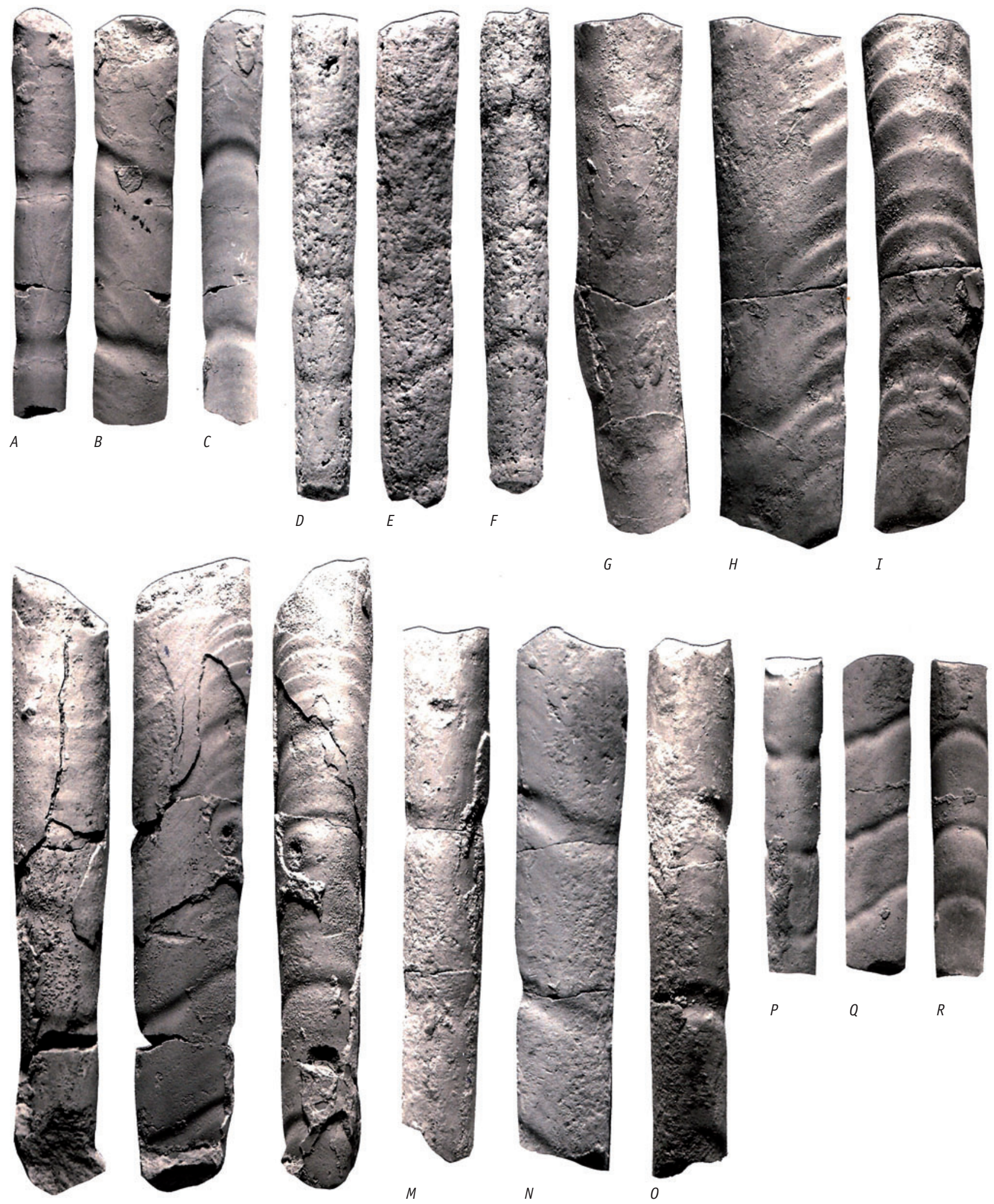

Fig. 18A-R. Sciponoceras baculoides (Mantell, 1822), A-C are IRSCNB 11467; G-I are IRSCNB 11468; J-L are IRSCNB 11469; P-R are IRSCNB 11470, Tourtia de Tournai, Tournai (Hainaut); D-F are IRSCNB 11471; M-O are IRSCNB 11472, Tourtia de Tournai, Chercq (Hainaut). All figures are $\times 2$. 


\section{Description}

IRScNB 11480 are tiny fragments of internal moulds of phragmo-

Fig. 19J-L.

1959 Sciponoceras roto Cieśliński, pp. 39, 75, 89, text-fig. 14(2); pl. 4, fig. 10.

1995 Sciponoceras roto Cieśliński, 1959; Wright \& Kennedy, p. 315, text-figs 131 j-l, n; pl. 94, figs 3-19; pl. 95, fig. 4; pl. 98, fig. 28 (with full synonymy).

1996 Sciponoceras roto Cieśliński, 1959; Kennedy in Gale et al., p. 580 , figs $23 a-d, j, k$.

1998 Sciponoceras roto Cieśliński, 1959; Kaplan et al., p. 186, pl. 13, figs 9, 10.

\section{Types}

Cieśliński (1959) based this species nine syntypes from the Cenomanian of Poland.

\section{Material}

IRScNB 11477, from the Tourtia de Tournai of Tournai, Hainaut, and IRScNB 11480, from the Tourtia de Tournai of Carrière du Cornet, Chercq, near Tournai, Hainaut.

cone with a subcircular whorl section and a maximum preserved whorl height of $5 \mathrm{~mm}$. The larger specimen consists of three camerae, and is smooth apart from a single constriction. IRScNB 11477 is a $27 \mathrm{~mm}$ long fragment retaining replaced, limonitestained shell. The whorl section is circular, with a maximum preserved whorl height of $7.2 \mathrm{~mm}$. The surface of the shell is smooth but for a prominent constriction that is transverse and weak on the dorsum, weakly prorsiradiate on the flanks, and crosses the venter in a broad convexity.

\section{Discussion}

Whorl section and wide spacing of constrictions show these fragments to be Sci. roto.

\section{Occurrence}

In addition to the present records, the species is known from Westfalen (Germany), southern England, France, Tunisia, Kazakhstan, South Africa and Madagascar. This is an Early Cenomanian species where well dated, but may range into the lower Middle Cenomanian. It is said to range throughout the Cenomanian in Poland (Marcinowski, 1980, p. 254).
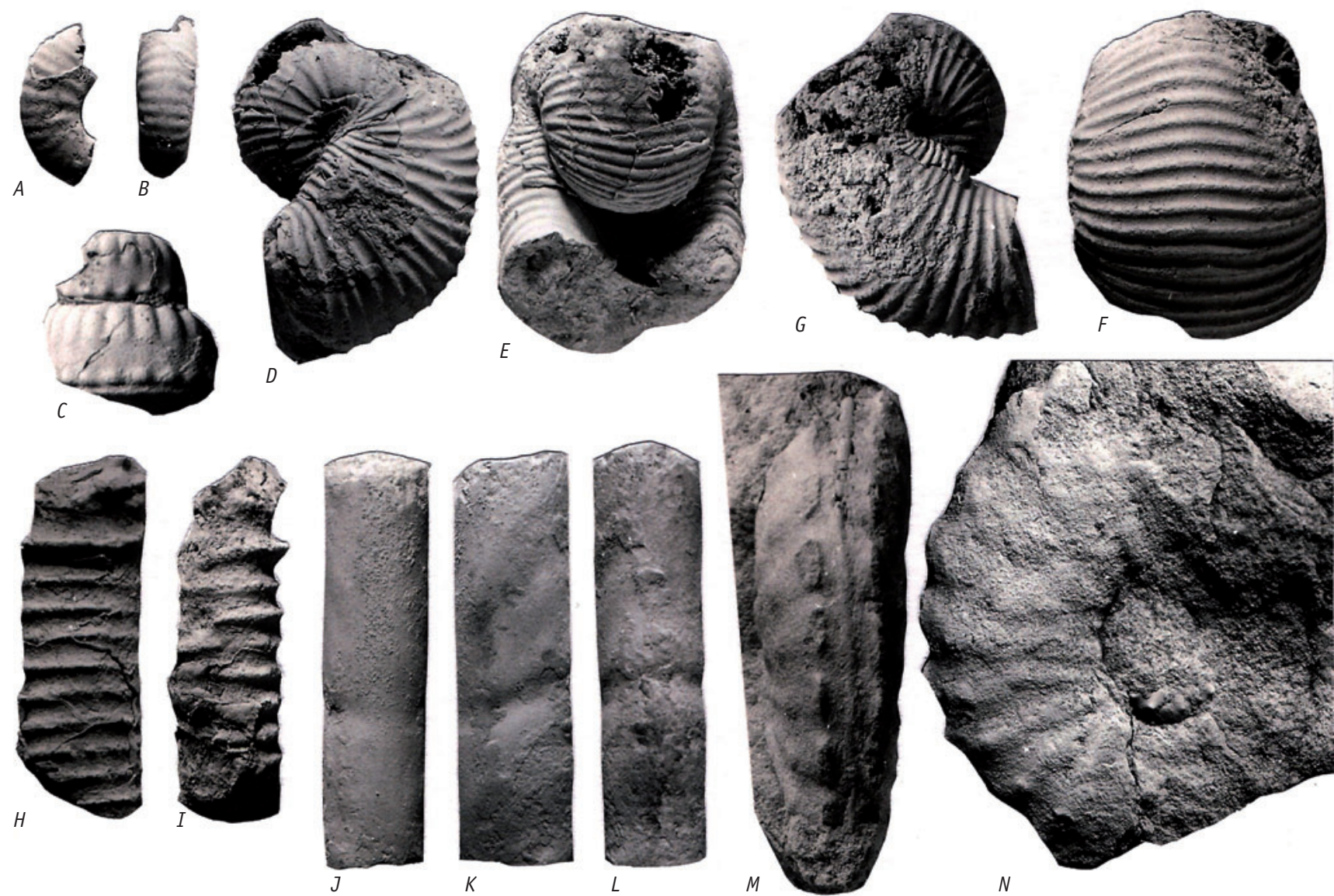

Fig. 19A, B. Scaphites sp., IRSCNB 11473, Tourtia of Montignies-sur-Roc, Hainaut; C. Mesoturrilites corrugatus Wright \& Kennedy, 1996, IRScNB 11474, Tourtia de Tournai, Tournai (Hainaut); D-G. Scaphites obliquus J. Sowerby, 1813, IRScNB 11475, Tourtia de Tournai, Tournai, Hainaut; H, I. Hamites simplex d'Orbigny, 1842, IRSCNB 11476, Tourtia de Tournai, Tournai (Hainaut); J-L. Sciponoceras roto Cieśliński, 1959, IRSCNB 11477, Tourtia de Tournai, Tournai (Hainaut); M, N. Acompsoceras inconstans (Schlüter, 1871), IRSCNB 11478, Meule de Bernissart, Onnaing-les-Valenciennes (Nord, France). Figures A-L are $\times 2$; M-N are $\times 1$. 
Superfamily Scaphitoidea Gill, 1871

Family Scaphitidae Gill, 1871

Subfamily Scaphitinae Gill, 1871

Genus Scaphites Parkinson, 1811

\section{Type species}

Scaphites equalis J. Sowerby, 1813, p. 53, pl. 18, figs 1-3, by the subsequent designation of Meek (1876, p. 413).

Scaphites obliquus J. Sowerby, 1813

Fig. 19D-G.

1813 Scaphites obliquus J. Sowerby, p. 54, pl. 18, figs 4-7.

1996 Scaphites obliquus J. Sowerby, 1813; Wright \& Kennedy, p. 390, pl. 114, figs 7-20; pl. 115, figs 1-17; pl. 116, fig. 6; text-fig. 150f, k (with full synonymy).

1998 Scaphites obliquus J. Sowerby, 1813; Kaplan et al., p. 223, pl. 13, figs 11, 12; pl. 60, fig. 3; pl. 66, figs 1-7, 9, 10.

\section{Type}

The lectotype is BMNH 43987a from the Lower Chalk of Hamsey (Sussex, England), the original of J. Sowerby (1813, p. 54, pl. 18, figs 4-6), designated by Kennedy (1971, p. 33) and reillustrated by Wright \& Kennedy (1996, pl. 114, fig. 18).

\section{Material}

IRSCNB 11475, from the Tourtia de Tournai of Tournai, Hainaut.

\section{Description}

The specimen is limonitised and retains limonitic shell. It consists of a phragmocone, $15 \mathrm{~mm}$ in diameter, and the adapical part of the body chamber shaft of a macroconch. The coiling of the phragmocone is very involute, the umbilicus largely concealed by the umbilical margin of the succeeding shaft; the whorl section is depressed reniform. Crowded narrow sharp ribs are straight and rursiradiate on the inner flanks. They branch on the flank and additional ribs intercalate; the ribs are transverse to feebly concave across the venter. The adapical section of the body chamber has a very depressed, reniform cross section, with a whorl breadth to height ratio of 1.6. There is a bulge on the umbilical seam that partially conceals the umbilicus of the spire. Adaperturally of this, the umbilical wall is broadly convex. Sharp, narrow, crowded ribs become increasingly prorsiradiate adaperturally; they are straight on the inner flank and increase by branching and intercalation, convex on the ventrolateral shoulder, initially concave at midventer but becoming transverse on the adapertural ribs.

\section{Discussion}

Scaphites obliquus co-occurs with Sc. equalis J. Sowerby, 1813 over part of its range. They differ in the development of few coarse distant primary ribs on the flanks of the latter (see revision in Wright \& Kennedy, 1996, p. 394, text-figs 153 (pars), 154 c, d; pl. 116, figs 1-5, 7-11; pl. 117, figs 1-11; pl. 118, figs 1-13).

\section{Occurrence}

Scaphites obliquus ranges from the base of the Hypoturrilites carcitanese Subzone of the Lower Cenomanian Mantelliceras mantelli Zone to the lower Upper Cenomanian Calycoceras guerangeri Zone. The geographic distribution extends from southern England to Belgium (the present record), Westfalen (Germany), France, Switzerland, Ukraine, Russia, Turkmenistan, Iran, Algeria and Tunisia, southern India and perhaps Madagascar.

Scaphites sp.

Fig. 19A, B.

\section{Material}

IRScNB 11473, from the Tourtia of Montignies-sur-Roc, Hainaut.

\section{Description and discussion}

This tiny fragment of a $120^{\circ}$ sector of phragmocone has a maximum preserved whorl height of $4.6 \mathrm{~mm}$. The whorl breadth to height ratio is around 1 . The umbilical wall and shoulder are quite narrowly rounded. The flanks are feebly convex, the ventrolateral shoulders broadly rounded, the venter very feebly convex. Five relatively coarse primary ribs arise on the umbilical wall and are straight and feebly prorsiradiate on the inner flank. Most bifurcate around mid-flank, to give a total of 14 ribs at the ventrolateral shoulder, the secondary ribs feebly concave on the outer flanks and ventrolateral shoulders, and straight or feebly convex over the venter. The suture is only moderately incised, with a broad, asymmetrically bifid E/A, narrower bifid A.

\section{Occurrence}

As for material.

Fig. 20. Turrilites acutus Passy, 1832, NHMW 1857 XX 6, Tourtia de Tournai, Tournai (Hainaut), $\times 2$.

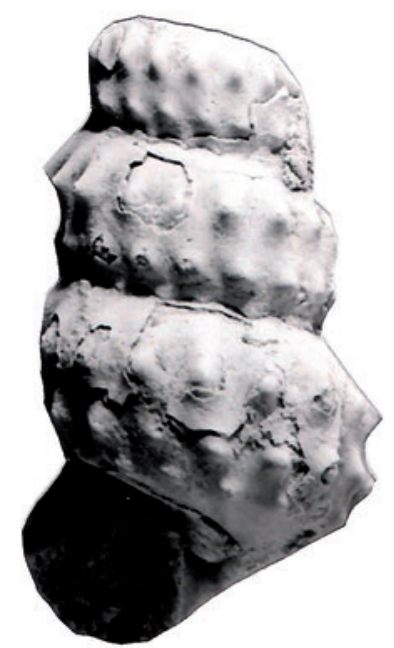




\section{Conclusions}

In the first place, the present study of ammonites preserved in the IRSCNB collections confirms the stratigraphic attribution of the various tourtias which Amédro \& Robaszynski (2010) recognised. Their sequence-stratigraphic interpretation of the tourtias (see Fig. 8) envisages a succession of third-order transgressive intervals which expressed themselves on the western margin of the Paris Basin up to the Mons Basin, by glauconitic microconglomeratic facies, or tourtias. These transgressive intervals are linked both to sea level drops and rapid sea level rises and covered increasingly larger areas during the great transgression of the Chalk sea. Each transgressive pulse is underlined by increasingly younger tourtias, to which names of different localities have been given.

Secondly, novelties reside in the punctuated presence, here and there, of outliers of Lower Cenomanian strata into the Mons Basin and beyond. The presence of Mantelliceras dixoni at Sassegnies, as well as of the typically late Early Cenomanian (Mantelliceras dixoni Zone) Acompsoceras inconstans and A. renevieri at Hautrage, Onnaing and Sassegnies, suggest that, by extension, the remains of Lower Cenomanian which cannot be dated with more precision at Tournai and Bettrechies may also be of comparable age, i.e., Mantelliceras dixoni Zone.

\section{Acknowledgements}

We thank the late Jake M. Hancock for assistance with the identification of the Tourtia Schloenbachia, advice on the marginal Late Cretaceous facies of Hainaut (Belgium) and of Nord (France) and his field observations (Fig. 4 here), Herbert Summesberger (Naturhistorisches Museum Wien, Vienna), Abel Prieur (Université Claude Bernard, Lyon), the late Annie V. Dhondt and Annelise Folie (Institut royal des Sciences naturelles de Belgique, Brussels) and Lindsay Percival (The Natural History Museum, London) for access to specimens in their care. The technical support of the staff of the 0xford University Museum of Natural History and Department of Earth Sciences (0xford) is gratefully acknowledged. We are also grateful to Bertrand Matrion (Troyes) for drafting all figures.

\section{References}

Amédro, F. \& Robaszynski, F., 2010. La transgression cénomanienne et l'âge des Tourtias, du Nord du Bassin de Paris (F) et du Bassin de Mons (B). Bulletin d'Information des Géologues du Bassin de Paris 47: 7-35.

Barrois, C., 1878. Mémoire sur le terrain crétacé des Ardennes et des régions voisines. Annales de la Société géologique du Nord 5: 227-487.

Barroso-Barcenilla, F., 2007. Revision and new data of the ammonite family Acanthoceratidae de Grossouvre, 1894, from the lower Turonian of the Iberian trough, Spain. Palaeontographica A280: 123-163.
Bosc, L.A.G., 1801 (An 13). In: Roissy, F. Histoire naturelle générale et particulière des mollusques, animaux sans vertèbres et à sang blanc. Ouvrage faisant suite aux oeuvres de Leclerc de Buffon, et partie du cours complet d'histoire naturelle, rédigé par C.S. Sonnini, membre de plusiers sociétés savantes. Continué par. F. de Roissy. Dufour et d'0cagne (Paris): viii + 1-448 + 1-3.

Breistroffer, M., 1947. Notes de nomenclature paléozoologique. Procès-verbaux mensuels de la Société scientifique du Dauphiné 26 (195): 5 pp. (unpaginated).

Breistroffer, M., 1953. L'évolution des turrilitidés albiens et cénomaniens. Comptes Rendus hebdomadaires des Séances de l'Académie des Sciences, Paris D237: 1349-1351.

Brongniart, A., 1822. Sur quelques terrains de Craie hors du Bassin de Paris, pp. 80-101. In: Cuvier, G. \& Brongniart, A. (eds): Description géologique des environs de Paris ( $3^{\text {rd }}$ edition). Dufour et d'0cagne (Paris): 1-428.

Bronn, H.G., 1851-1852. V. Vierte Periode: Kreide-Gebirge. In: Bronn, H.G. \& Roemer, F., 1850-1856. H.G. Bronn's Lethaea Geognostica. Dritte stark vermehrte Auflage. E. Schweizerbart'sche Verlagsbuchhandlung (Stuttgart): i-iv + 3-412.

Cayeux, L., 1889. Notes sur le Crétacé de Chercq près Tournay. Annales de la Société géologique du Nord $16: 142-156$.

Cieśliński, S., 1959. Alb i Cenoman północnego obrzeżenia Gór Świętokrzyskich. Instytut Geologiczny Prace 28: 1-95.

Cobban, W.A. \& Hook, S.C., 1983. Mid-Cretaceous (Turonian) ammonite fauna from Fence Lake area, west-central New Mexico. Memoir of the New Mexico Bureau of Mines and Mineral Resources 41: 1-50.

Cobban, W.A., Hook, S.C. \& Kennedy, W.J., 1989. Upper Cretaceous rocks and ammonite faunas of southwestern New Mexico. Memoir of the New Mexico Bureau of Mines and Mineral Resources 45: 1-137.

Coquand, H., 1862. Géologie et paléontologie de la région de la Province de Constantine. Mémoires de la Société d'Emulation de la Provence 2:1-341.

Cornet, F.-L. \& Briart, A., 1866. Description minéralogique, paléontologique et géologique du terrain crétacé de la province du Hainaut. Mémoire couronné par la Société des Sciences, des Arts et des Lettres du Hainaut (1863-1864). Dequesne-Masquillier (Mons): 1-198.

d'Archiac, A., 1846. Rapport sur les fossiles du poudingue nervien (tourtia) légués par M. Léveillé à la Société géologique de France. Bulletin de la Société géologique de France (2)3: 332- 338.

d'Archiac, A., 1847. Rapport sur les fossiles du Tourtia légués par M. Léveillé à la Société géologique de France. Mémoires de la Société géologique de France (2) 2: 291-351.

De Grossouvre, A., 1894. Recherches sur la Craie supérieure, 2. Paléontologie. Les ammonites de la Craie supérieure. Mémoires pour servir à l'explication de la carte géologique détaillée de la France. Imprimerie Nationale (Paris): 1-264 (misdated 1893).

Diener, C., 1925. Ammonoidea neocretacea. Fossilium Catalogus, 1. Animalia, Pars 29. W. Junk (Berlin): 1-244.

d'Orbigny, A., 1840-1842. Paléontologie Française. Terrains crétacés, 1. Céphalopodes. Masson (Paris): 1-120 (1840); 121-430 (1841); 431-662 (1842).

d'Orbigny, A., 1850. Prodrome de paléontologie stratigraphique universelle des animaux mollusques et rayonnés faisant suite au cours élémentaire de paléontologie et de géologie stratigraphique, 2. Masson (Paris): 1-427.

Douvillé, H., 1890. Sur la classification des Cératites de la Craie. Bulletin de la Société géologique de France (3)18: 275-292. 
Douvillé, H., 1912. Evolution et classification des Pulchelliidés. Bulletin de la Société géologique de France (4)11: 285-320.

Drapiez, A., 1823. Coup d'œil minéralogique et géologique sur la province du Hainaut, royaume des Pays-Bas. Mémoires couronnés par l'Académie royale des Sciences et Belles Lettres de Bruxelles 3: 1-164.

Dumont, A., 1849. Rapport sur la carte géologique du royaume. Bulletin de l'Académie royale de Belgique (1)16: 351-373.

Fieber, F.X., 1853. Synopsis der europäischen Orthopteren mit besonderer Rücksicht der böhmischen Arten. Lotos 3: 90-104, 115-129, 138-154, 168-176, 184-188, 201-107, 232-238, 252-261.

Gale, A.S., Kennedy, W.J., Burnett, J.A., Caron, M. \& Kidd, B.E., 1996. The Late Albian to early Cenomanian succession at Mont Risou, near Rosans (Drôme, SE France): an integrated study (ammonites, inoceramids, planktonic foraminifera, nannofossils, oxygen and carbon stable isotopes). Cretaceous Research 17: 515-606.

Gale, A.S., Hancock, J.M. \& Kennedy, W.J., 1999. Biostratigraphical and sequence correlation of the Cenomanian sucessions in Mangyshlak (W. Kazakhstan) and Crimea (Ukraine) with those in southern England. Bulletin de l'Institut royal des Sciences naturelles de Belgique, Sciences de la Terre 69, Supplement A: 67-86.

Gauthier, H., 2006. Révision critique de la Paléontologie Française d'Alcide d'0rbigny, 6. Céphalopodes crétacés. Backhuys (Leiden): 1-292 + 1-662 +1-28.

Gill, T., 1871. Arrangement of the families of mollusks. Smithsonian Miscellaneous Collections 227: xvi +1-49.

Gosselet, J., 1881. Esquisse géologique du Nord de la France et des contrées voisines. $2^{\text {ème }}$ fascicule: terrains secondaires. Six-Horemans (Lille): 169-278.

Gosselet, J., 1904-1914. Les assises crétaciques et tertiaires dans les fosses et sondages du Nord de la France. Imprimerie nationale (Paris): 1-420.

Haas, 0., 1946. Intraspecific variation in, and ontogeny of, Prionotropis woollgari and Prionocyclus wyomingensis. Bulletin of the American Museum of Natural History 86: 141-224.

Hyatt, A., 1889. Genesis of the Arietidae. Smithsonian Contributions to Knowledge 673: $x i+1-239$.

Hyatt, A., 1894. Phylogeny of an acquired characteristic. Proceedings of the American Philosophical Society 32: 349-647.

Hyatt, A., 1900. Cephalopoda. In: Zittel, K.A. von (Eastman, C.R.). Textbook of palaeontology. Macmillan (London/New York): 502-604.

Hyatt, A., 1903. Pseudoceratites of the Cretaceous. United States Geological Society Monograph 44: 1-351.

Juignet, P. \& Kennedy, W.J., 1976. Faunes d'ammonites et biostratigraphie comparée du Cénomanien du nord-ouest de la France (Normandie) et du sud d'Angleterre. Bulletin trimestriel de la Société géologique de Normandie et des Amis du Muséum du Havre 63: 1-193.

Kaplan, U., Kennedy, W.J., Lehmann, J. \& Marcinowski, R., 1998. Stratigraphie und Ammonitenfaunen des westfälischen Cenoman. Geologie und Paläontologie in Westfalen 51: 1-236.

Kennedy, W.J., 1971. Cenomanian ammonites from southern England. Special Papers in Palaeontology 8: $\mathrm{v}+1-133$.

Kennedy, W.J., Chahida, M.R. \& Djafarian, M.A., 1979. Cenomanian cephalopods from the Glauconitic Limestone southeast of Esfahan. Acta Geologica Polonica 24: 3-50.
Kennedy, W.J., Cobban, W.A. \& Landman, N.H., 2001. A revision of the Turonian members of the ammonite subfamily Collignoniceratinae from the United States Western Interior and Gulf Coast. Bulletin of the American Museum of Natural History 267, 1-148.

Kennedy, W.J., Gale, A.S., Ward, D.J. \& Underwood, C.J., 2008. Lower Turonian ammonites from Goulmima, southern Morocco. In: Steurbaut, E., Jagt, J.W.M. \& Jagt-Yazykova, E.A. (eds): Annie V. Dhondt Memorial Volume. Bulletin de l'Institut royal des Sciences naturelles de Belgique, Sciences de la Terre 78: 149-177.

Kennedy, W.J. \& Hancock, J.M., 1970. Ammonites of the genus Acanthoceras from the Cenomanian of Rouen, France. Palaeontology 13: 462-490.

Kennedy, W.J., King, C. \& Ward, D.J., 2008. The upper Albian and lower Cenomanian succession at Kolbay, eastern Mangyshlak (southwest Kazakhstan). In: Steurbaut, E., Jagt, J.W.M. \& Jagt-Yazykova, E.A. (eds): Annie V. Dhondt Memorial Volume. Bulletin de l'Institut royal des Sciences naturelles de Belgique, Sciences de la Terre 78: 117-147.

Korn, D., Ebbighausen, V., Bockwinkel, J. \& Klug, C., 2003. The A-mode sutural ontogeny in prolecanitid ammonoids. Palaeontology 46: 1123-1132.

Kossmat, F., 1895-1898. Untersuchungen über die südindische Kreideformation. Beiträge zur Geologie und Paläontologie Österreich-Ungarns und des Orients 9 (1895): 97-203 (1-107); 11 (1897): 1-46 (108-153); 11 (1898): 89-152 (154-217).

Kullmann, J. \& Wiedmann, J., 1970. Significance of sutures in phylogeny of Ammonoidea. Paleontological Contributions, University of Kansas 47: 1-32.

Lamarck, J.B.P.A. de M., 1801. Système des animaux sans vertèbres. The author/Déterville (Paris): vii + 1-432.

Laube, G.C. \& Brüder, G., 1887. Ammoniten der böhmischen Kreide. Palaeontographica 33: 217-239.

Lehmann, J. \& Herbig, H.-G., 2009. Late Cretaceous ammonites from the Bou Anguer syncline (Middle Atlas, Morocco) - stratigraphic and paleobiogeographic implications. Palaeontographica A289: 45-87

Mantell, G.A., 1822. The fossils of the South Downs; or illustrations of the geology of Sussex. Lupton Relfe (London): xvi + 1-327.

Marcinowski, R., 1974. The transgressive Cretaceous (Upper Albian through Turonian) deposits of the Polish Jura Chain. Acta Geologica Polonica 24: 117-217.

Marcinowski, $R$., 1980. Cenomanian ammonites from the German Democratic Republic, Poland and the Soviet Union. Acta Geologica Polonica 30: 215-325.

Marlière, $\boldsymbol{R}$., 1936. Sur l'Albien et le Cénomanien dans le Nord de la France et le Bassin de Mons: Meule, Grès vert, Vraconnien. (Note préliminaire). Annales de la Société géologique de Belgique 60: B132-B140.

Marlière, $\boldsymbol{R} ., 1939$ a. Le sondage no 10 du Charbonnage de Bray (1938). Annales de la Société géologique de Belgique 62: B323-B326.

Marlière, $R_{\text {., }} 1939 \mathrm{~b}$. Contribution à l'étude des formations crétacées et tertiaires du Bassin de Mons. Deuxième fascicule. Annales de la Société géologique de Belgique 63: B50-B76 (B52-B78).

Marlière, $R ., 1939$ c. La transgression albienne et cénomanienne dans le Hainaut (études paléontologiques et stratigraphiques). Mémoire du Musée royal d'Histoire naturelle de Belgique 89: 1-440.

Marlière, R., 1957. (Entries on tourtias at various localities). In: Sornay, J. (ed.): Lexique stratigraphique international, Fascicule 4a VI: Europe - France, Belgique, Pays-Bas, Luxembourg. Centre National de la Recherche Scientifique (Paris): 1-403. 
Meek, F.B., 1876. A report on the invertebrate Cretaceous and Tertiary fossils of the upper Missouri country. In: Hayden, F.V.: Report of the United States Geological Survey of the Territories 9: lxiv + 1-629.

Neumayr, M., 1875. Die Ammoniten der Kreide und die Systematik der Ammonitiden. Zeitschrift der deutschen geologischen Gesellschaft 27: 854-942.

Noetling, F., 1885. Die Fauna der baltischen Cenoman-Geschiebe. Palaeontologische Abhandlungen 2: 199-247.

Parkinson, J., 1811. Organic remains of a former world, 3. J. Robson (London): 1-479.

Passy, A., 1832. Description géologique du département de la Seine-Inférieure. Imprimerie de Nicétas Periaux (Rouen): xvi + 1-371.

Pervinquière, L., 1907. Etudes de paléontologie tunisienne, 1. Céphalopodes des terrains secondaires. Carte géologique de la Tunisie. F.R. de Rudeval (Paris): $\mathrm{i}-\mathrm{v}+1-438$.

Pictet, F.J., 1847. In: Pictet, F.J. \& Roux, W., 1847-1854: Description des mollusques fossiles qui se trouvent dans les Grès Verts des environs de Genève. Mémoires de la Société de Physique et d'Histoire naturelle de Genève 11 (1847): 257-42; 12 (1849): 21-151; 13 (1852): 73-173; 14 (1854): 279-341.

Pictet, F.J. \& Campiche, G., 1861-1864. Description des fossils du terrain crétacé des environs de Sainte-Croix, 2. Matériaux pour la Paléontologie Suisse (2)2: 1-752.

Polvêche, J., 1957. Tourtia (France, Nord, Pas-de-Calais). In: Sornay, J. (ed.): Lexique stratigraphique international, Fascicule 4a VI: Europe - France, Belgique, Pays-Bas, Luxembourg. Centre National de la Recherche Scientifique (Paris): 346-348.

Robaszynski, F., 1980a. Bettrechies (France). Carrière SECAB (ancienne carrière de la gare de Bettrechies). In: Alcaydé, G., Bless, M.J.M., Juignet, P., Médioni, R., Meessen, J.P.M.T., Neumann, M., Platel, J.-P., Robaszynski, F. \& Streel, M.: Stratotypes et coupes représentatives du Crétacé moyen et supérieur de Maastricht au Périgord. Bulletin d'Information des Géologues du Bassin de Paris 16: 114.

Robaszynski, F., 1980b. Tourtias (Nord de la France, Hainaut belge). In: Mégnien, C. \& Mégnien, F. (eds): Synthèse géologique du Bassin de Paris, volume III: lexique des noms de formations. Mémoires du Bureau de Recherches géologiques et minières 103: 321-322.

Robaszynski, F., Dhondt, A.V. \& Jagt, J.W.M., 2002. Cretaceous lithostratigraphic units (Belgium). In: Bultynck, P. \& Dejonghe, L. (eds): Guide to a revised lithostratigraphic scale of Belgium. Geologica Belgica 4 (2001): 121-134.

Schlüter, C., 1871-1876. Cephalopoden der oberen deutschen Kreide. Palaeontographica 21: 1-24 (1871); 21: 25-120 (1872); 24: 1-144 (121-264) + i-x (1876).

Sharpe, $D$., 1853-1857. Description of the fossil remains of Mollusca found in the Chalk of England, I. Cephalopoda. Monographs of the Palaeontographical Society London: 1-26 (1853); 27-36 (1855); 37-68 (1857).

Sornay, J., 1955. Hamites simplex d'0rbigny, 1840. Paleontologia Universalis, n.s. fiche 18: 1-2.

Sowerby, J., 1812-1822. The mineral conchology of Great Britain. The author (London): 1: 1-234; 2: 1-251; 3: 1-184; 4: 1-114.

Sowerby, J., 1823-1846. The mineral conchology of Great Britain (continued). The author (London): 4: 115-148; 5: 1-168; 6: 1-230; 7: 1-80.

Spath, L.F., 1922. On the Senonian ammonite fauna of Pondoland. Transactions of the Royal Society of South Africa 10: 113-147.

Spath, L.F., 1923. On the ammonite horizons of the Gault and contiguous deposits. Summary of Progress of the Geological Survey of Great Britain and the Museum of Practical Geology 1922: 139-149.
Spath, L.F., 1926a. On the zones of the Cenomanian and the uppermost Albian. Proceedings of the Geologists' Association 37: 420-432.

Spath, L.F., 1926b. On new ammonites from the English Chalk. Geological Magazine 63: 77-83.

Spath, L.F., 1928. A. monograph of the Ammonoidea of the Gault, Part 6. Monographs of the Palaeontographical Society London: 207-266.

Spath, L.F., 1938. Problems of ammonite nomenclature, 3. On Ammonites varians J. Sowerby. Geological Magazine 75: 543-547.

Spath, L.F., 1939. Problems of ammonite nomenclature, 6. The genus Pachydiscus Zittel. Geological Magazine 74: 277-281.

Stieler, K., 1922. Über Gault- und Cenoman-Ammoniten aus dem Cenoman des Cap Blanc Nez, mit besonderer Berücksichtigung der Gattung Schloenbachia Neumayr. Neues Jahrbuch fur Geologie, Mineralogie und Paläontologie, Beilage-Band 47: 19-44.

Thomel, G., 1972. Les Acanthoceratidae cénomaniens des chaînes subalpines méridionales. Mémoires de la Société géologique de France, nouvelle série 116: $1-204$

Thomel, G., 1992. Ammonites du Cénomanien et du Turonien du sud-est de la France, 1-2. Serre (Nice): 1-422; 1-383.

Von Zittel, K.A., 1884. Handbuch der Palaeontologie, 1. Abteilung 2; Lieferung 3. Cephalopoda. R. Oldenbourg (München/Leipzig): 329-522.

Von Zittel, K.A., 1895. Grundzüge der Palaeontologie (Palaeozoologie). R. Oldenbourg (München/Leipzig): vii + 1-972.

Wiedmann, J., 1966. Stammesgeschichte und System der posttriadischen Ammonoideen; ein Überblick. Neues Jahrbuch fur Geologie und Paläontologie Abhandlungen 125: 49-79; 127: 13-81.

Wiedmann, J. \& Schneider, H.L., 1979. Cephalopoden und Alter der CenomanTransgression von Mülheim-Broich, SW-Westfalen. In: Wiedmann, J. (ed.): Aspekte der Kreide Europas. International Union of Geological Sciences (A)6: 645-680.

Wilmsen, M. \& Mosavinia, A., 2011. Phenotypic plasticity and taxonomy of Schloenbachia varians (J. Sowerby, 1817) (Cretaceous Ammonoidea). Paläontologische Zeitschrift 85: 169-184.

Wright, C.W., 1979. The ammonites of the English Chalk Rock. Bulletin of the British Museum (Natural History), Geology 31: 281-332.

Wright, C.W. \& Kennedy, W.J., 1981. The Ammonoidea of the Plenus Marls and the Middle Chalk. Monographs of the Palaeontographical Society London 134 (560): 1-148.

Wright, C.W. \& Kennedy, W.J., 1984. The Ammonoidea of the Lower Chalk, Part 1. Monograph of the Palaeontographical Society London 137 (537): 1126.

Wright, C.W. \& Kennedy, W.J., 1987. The Ammonoidea of the Lower Chalk, Part 2. Monograph of the Palaeontographical Society London 139(573): 127-218.

Wright, C.W. \& Kennedy, W.J., 1995. A monograph of the Ammonoidea of the Lower Chalk, Part 4. Monograph of the Palaeontographical Society London 149 (599): 295319.

Wright, C.W. \& Kennedy, W.J., 1996. A monograph of the Ammonoidea of the Lower Chalk, Part 5. Monograph of the Palaeontographical Society London 150 (601): 320403.

Wright, C.W. \& Wright, E.V., 1951. A survey of the fossil Cephalopoda of the Chalk of Great Britain. Monographs of the Palaeontographical Society London 104: 1-41. 